\title{
ГЕОЛОГИЯ АПТ-АЛЬБСКИХ ПОРОД КАРБОНАТНОЙ ПЛАТФОРМЫ ОСАДОЧНОЙ ГРУППЫ КОГОЛЛО И ПОСЛЕДСТВИЯ АНОКСИДНЫХ ОКЕАНИЧЕСКИХ СОБЫТИЙ БАССЕЙНА МАРАКАЙБО (СЕВЕРО-ЗАПАДНАЯ ЧАСТЬ ЮЖНОЙ АМЕРИКИ)
}

\author{
Аура Самид Гарсия Бальса, \\ garciaas@hw.tpu.ru \\ Национальный исследовательский Томский политехнический университет, \\ Россия, 635050, г. Томск, пр. Ленина, 30.
}

\begin{abstract}
Актуальность исследования обусловлена необходимостью проведения дополнительных поисково-разведочных работ на нефть и газ в северо-западной части нефтегазоносного бассейна Маракайбо, которые позволят повысить рентабельность разработки действующих месторождений и расширят возможности поиска новых залежей углеводородов в западной части Венесуэлы. Анализируемая осадочная толща Коголло, представленная формациями Апон, Лижур и Марака, включает промышленно продуктивный интервал, который слагают карбонатные отложения и нефтематеринские породы мелового периода. Литологическая характеристика нефтематеринских пород указывает на аноксидные океанические события при формировании формации Апон. Первое событие соотносится с осадконакоплением пачки Мачикес, а второе - с кровлей пачки Пиче. Обе пачки принадлежат к формации Апон. Рассматриваемые события способствовали формированию нефтематеринских пород высокого генерационного потенциала углеводородов, чем объясняется интерес данного исследования.

Основной целью исследования является изучение фациальных условий формирования отложений формации Апон в разрезе обнажения континентальной части бассейна Маракайбо и их корреляция с ближайшими глубокими скважинами для определения стратиграфического местоположения коллекторов и их возможной связи с интервалами потенциальной нефтематеринской породы.

Объекты: обнажения карьера Цементос Кататумбо С.А. в горной системе Периха, где выделяется карбонатная тоща нижней группы Коголло, а также глубокие поисковые скважины X-1, X-15, X-21, X-14 и X-23. Имеющиеся варианты корреляции отложений в обнажении горной системы Периха недостаточно обоснованы и требуют уточнения.

Методы: седиментологический и геохимический анализы карбонатных пород группы Коголло в пределах в карьере Цементос Кататумбо С.А., штат Сулия, Венесуэла, включающие макро- и петрографическое описание пород, биостратиграфический анализ, изучение содержания общего органического углерода в породе, данных гамма-каротажа по разрезу обнажения и в глубоких скважинах

Результаты. Выделено 14 микрофаций, связанных с условиями седиментации в пределах склона карбонатного бассейна. В последовательности переслаивания отложений формации Апон выделяются участки максимальной трансгрессии моря и скрытые стратиграфические несогласия. Аппроксимированная и оценочная корреляция, учитывающая стратиграфию, литофации и данные гамма-каротажа, была проведена в обнажении карьера Цементос Кататумбо С.А. и сопоставлена с разрезами нефтяных скважин X-1, Х-15, Х-21, Х-14 и Х-23.
\end{abstract}

\section{Ключевые слова:}

Карбонатная платформа, группа Коголло, формация Апон, бассейн Маракайбо, АOC 1а, АOC $1 б$.

\section{Введение}

Группа Коголло представляет собой классическую карбонатную платформу, образованную на седиментационном склоне в результате очень быстрой трансгрессии моря с конца барремского яруса до начала аптского яруса. Система формировалась в течение аптского и альбского ярусов, в бассейне Маракайбо, расположенном на северо-западе Венесуэлы (рис. 1).

Аноксидные океанические события (AOC) pacсматриваемой территории, характеризующиеся значительным снижением кислорода в придонной воде, были впервые описаны в качестве переходных периодов морской аноксии и повсеместного отложения органического материала богатого углеродом в течение мелового периода [1]. Наличие многочисленных прослоев черного сланца предполагает, что аноксидные океанические события, выделяемые как AOC-1, происходили неоднократно в течение среднего мелового периода. По стратиграфической приуроченности можно выделить четыре уровня: AOC-1а (ранний апт), АOC-1б (на границе апта-альба), АОС-1в (средний альб) и
AOC-1д (поздний альб) [2]. Рассматриваемые отложения кислородного голодания включают не только нефтеперспективные гемипелагические черносланцевые толщи [3], но и тонкие, богатые органически веществом, сланцы, переслаивающиеся с циклическими мелководными морскими карбонатами [4].

Группу Коголло в западной Венесуэле, представленную формациями Апон, Лижур и Марака, слагает сообщество карбонатных отложений и нефтематеринских пород мелового периода. Объектами изучения настоящей статьи являются нефтематеринские отложения формации Апон, соответствующие уровням аноксидной седиментации AOC-1a (пачка Мачикес) и AOC-1б (пачка Пиче).

Эти отложения выявлены в скважинах восточного побережья бассейна Маракайбо. На внутренней карбонатной платформе отложения уровня AOC-1a (пачка Мачикес) формировались на финальной стадии трансгрессии, а в последующий импульс расширения морского бассейна в конце апта (уровень АОС-1б) отлагалась пачка Пиче [5]. 

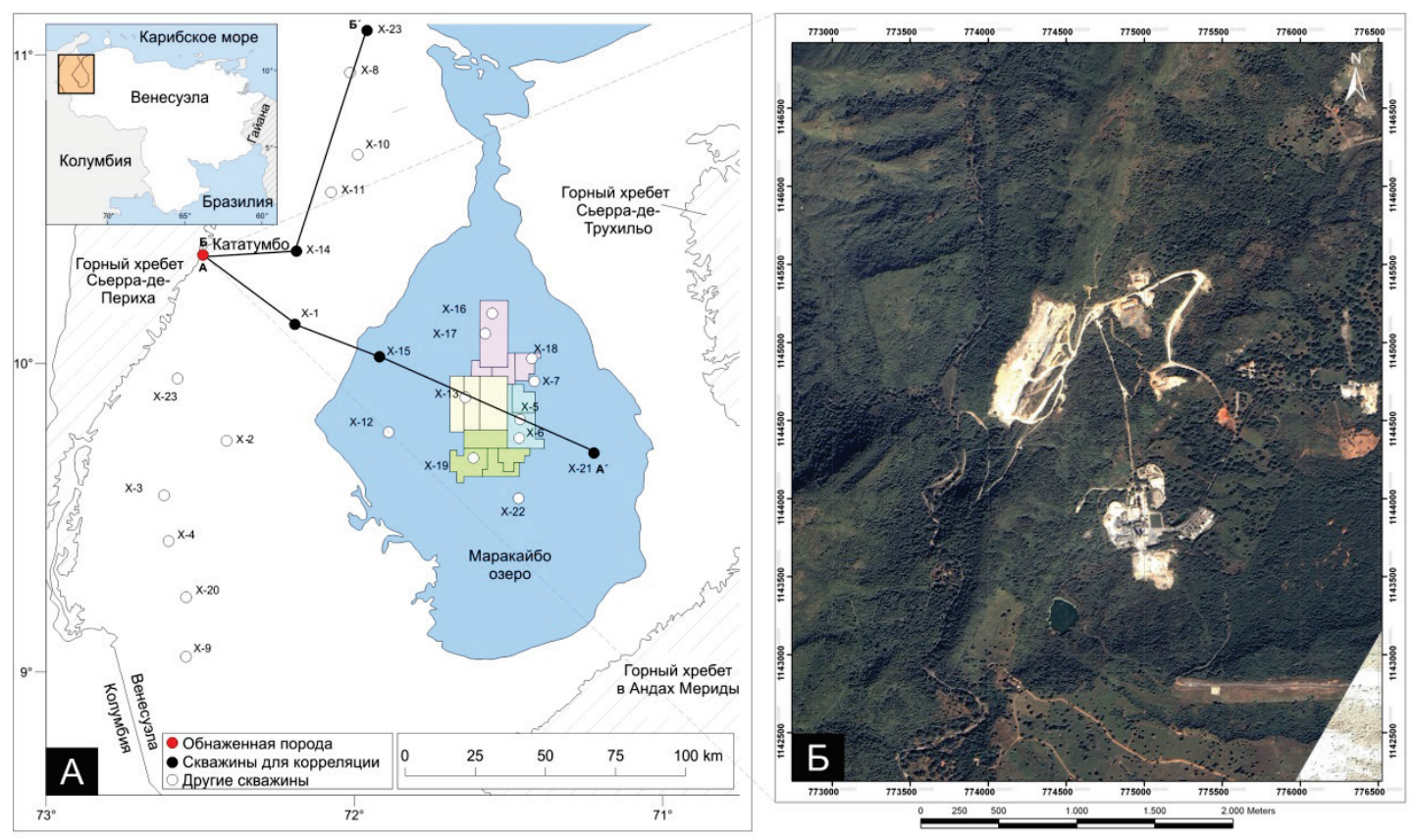

Pис.1. (А) Карта местоположения нефтяных скважин и обнажения Карьер Цементос Кататумбо С.А. в западной части бассейна Маракайбо; (Б) спутниковый снимок Иконос карьера в Цементос Кататумбо С.А.

Fig. 1. (A) Map of locations of oil wells and outcrop of quarry Cementos Catatumbo C.A. in western part of Maracaibo Basin; (Б) Satellite image Ikonos from the quarry of Cementos Catatumbo C.A.

Проведённые исследования обнажения подтвердили, что осадочные образования формации Апон в седиментационном бассейне Маракайбо представляют собой самостоятельный нефтегазоносный комплекс, аналогичный традиционному нефтегазоносному комплексу формации Ла Луна, в котором сосредоточено $98 \%$ общих объема запасов нефти в бассейне Маракайбо [6], а сама формация Ла Луна считается крупнейшей нефтепроизводящей толщей на Земле $[7,8]$.

В бассейне Маракайбо проведены исследования, связанные с осадкообразованием, диагенетической историей, типами пористости и трещиноватости меловых карбонатных отложений группы Коголло [5, 9, 10 и др.]. Однако геологическое изучение обнажений в Карьере Цементос Кататумбо С.А. не проводилось.

В статье рассматриваются вопросы изучения седиментации карбонатных пород апт-альбского возраста в западной части бассейна Маракайбо (район Карьера Цементос Кататумбо С. А.), включающие: 1) определение фаций и ассоциаций осадочных пород, позволяющее постулировать седиментологическую модель изучаемой осадочной толщи для дальнейшего прогноза ее пространственного распространения;

2) оценку диагенетических процессов и их влияние на коллекторские свойства продуктивных пластов;

3) сопоставление информации по поверхностным обнажениям пород и данным глубоких скважин с целью уточнения общей картины седиментации рассматриваемой территории.

\section{Геологическая обстановка}

Карибский бассейн - это зона взаимодействия пяти тектонических плит: плита Наска, плита Кокос, Южно-американская плита, Северо-американская плита и Карибская плита. Бассейн Маракайбо расположен на северо-западном крае плиты Южной Америки и охватывает большую часть Западной Венесуэлы, в так называемом блоке Маракайбо. Тектонический блок ограничен разломом Боконо в Мериде Анды, разломами системы Санта Марта-Букараманга, расположенными к западу от горной системы Периха в Колумбии, и системой разломов Оса-Анконе, простирающейся с запада на восток и идущей параллельно границе Карибской плиты [7, 11]. Взаимодействие Карибской плиты, Южно-Американской плиты и плиты Наска продвигает этот блок на северо-запад по отношению к Южной Америке. Бассейн Маракайбо это коса прибрежной полосы площадью 50000 км $^{2}$ и с суммарным объемом отложений $250000 \mathrm{kм}^{3}$, залегающих на древнем фундаменте [12]. Историю тектонической эволюции бассейна Маракайбо можно разделить на пять основных этапов. Первый этап - развитие в меловой период пассивной окраины континента; второй - формирование прибрежной полосы (поздний палеоцен-ранний эоцен), третий - позднеэоценовый тектонический прогиб и складчатость смятия, четвёртый - поднятие хребта Периха и блоковая складчатость (олигоцен-поздний миоцен); пятый - тектоническое влияние горной системы Анд (от плиоцена до настоящего времени) [13-15]. Геодинамическое развитие района охватывает длительный период, од- 
нако в представленной статье будет рассматриваться только ранний этап его эволюции.

После этапа континентального рифтогенеза и обширной субаэральной эрозии регион в начале мелового периода вошел в период относительного тектонического покоя и, как минимум до сеномана, представлял собой устойчивую платформу $[13,16,17]$. В барремском ярусе произошел общий подъем относительного уровня моря, в результате которого формируются отложения песков и конгломератов формации Рио-Негро [10]. Дальнейшая трансгрессия моря привела к тому, что терригенные отложения на обширных территориях сменились мелководными осадками карбонатной платформы с редким присутствием терригенных отложений, представленных группой Коголло $[10,18]$, которая включает формации Апон, Лижур и Маракас [19].

Формация Апон (апт-нижний альб) состоит из последовательности окаменелых известняков, с меньшей пропорцией иловых известняков (локально доломитизированных), доломитов и кремнисто-обломочных пород. В пределах центральной и северо-западной части бассейна Маракайбо формация представлена тремя пачками: Тибу, Мачикес и Пиче [20]. На формации Апон со стратиграфическим перерывом [19] залегает формация Лижур (средний альб), которая состоит из известково-глауконитовых кварцевых песчаников, глауконитовых печаных известняков, серых известняков, ракушечных известняков и некоторых сланцев [12]. Формация Маракас (поздний альб-сеноман) представлена массивными ракушняковыми и органогенно-обломочными известняками, преимущественно представленными Ostreas и Trigonia, с тонкими прослоями мергелей и глинистых сланцев, редким присутствием ооидов и покрытых зерен.

В сеноманский и туронский века бассейн Маракайбо испытывал неравномерное погружение, вызванное, вероятно, возобновлением тектонических подвижек блокового характера по разломам юрского периода, при этом прогибание западной части бассейна опережало восточную. Морская трансгрессия в позднем альбе-сеномане охватила большую часть площади платформы. Погружение дна седиментационного басссейна ниже фотической зоны предопределило смену карбонатного осадконакопления карбонатно-глинистым, что привело к формированию доманиковых отложений формации Ла Луна, являющейся нефтематеринской породой мирового класса и относящейся к уровню АОС-2 [5, 21, 22].

В дальнейшем, в результате тектонической активизации, произошло поднятие хребтов западной и центральной Колумбии, после чего между Карибской и северо-западным краем Южноамериканской плит в позднем палеоцене - среднем эоцене образовалась прогнутая зона осадконакопления, где толщина флювиально-дельтовых осадков достигает пяти километров.
Дальнейшее сближение тектонических плит в эоцен-олигоцене обусловило деформацию накопившейся толщи осадков $[7,14,23]$.

\section{Методология}

Формация Апон изучалась в 226 метровом интервале обнажения в северо-западной части бассейна Маракайбо. Исследование охватывает седиментологические характеристики формации Апон. Определение фаций осадконакопления и условий их формирования проводились на макроскопическом и микроскопическом уровнях с учетом фаунистических данных. Для этого в полевых условиях после литологического описания обнажения из 70 интервалов, распределенных по всему стратиграфическому разрезу, были отобраны образцы и изготовлены петрографические шлифы. Седиментологическая интерпретация окружающей среды и концептуальная модель осадконакопления базировались на критериях, упомянутых в работах $[24,25]$. По результатам петрографических исследований [26], учитывающих типы цементов (его морфологию и компоновку), характер различных диагенетических преобразований (микритизация, стилолитизация, уплотнение, замещение минералов) была определена парагенетическая последовательность формирования рассматриваемых отложений.

Кроме того, было отобрано 11 проб для исследований с помощью Rock-Eval 6 для определения значения общего органического углерода (массовый $\%$ ), которое затем было проверено повторным анализом. Все образцы были проанализированы в геологической лаборатории Эль Чауре (PDVSA S.A.).

При сопоставлении разреза обнажения с разрезами нефтяных скважин X-1, X-15, X-21, X-14 и $\mathrm{X}-23$ использованы седиментационные отчеты по этим скважинам, составленные разными авторами, работавшими над проектами PGO Golfo de Venezuela и PGP Guaraní (PDVSA).

На основе информации, полученной при изучении геологии обнажения и данных по скважинам, выполнены петрографические описания и проведен анализ диагенетических изменений пород, что позволило определить условия накопления и сохранения осадочных отложений в изучаемом регионе.

Это, в свою очередь, дало возможность установить взаимосвязь строения глубинных разрезов формации Апон с разрезом обнажения. Для более точной стратиграфической привязки анализируемых данных по скважинам в разрезе обнажения было проведено исследование гамма-излучения с помощью сцинтилляционного спектрометра. Показания снимались с интервалом в 50 сантиметров.

\section{Фации осадконакопления}

Фации, описанные на макроуровне, представляют собой первое приближение для интерпретации стратиграфической летописи. Было выделено шесть типов литофаций (ЛФТ): 
ЛФТ-1: Массивный известняк. Эта фация структурно содержит мадстоун, вакстоун и пакстоун. Для неё характерно беспорядочное расположение обломков трещиноватого и перекристаллизованного ракушечника. В основном это двустворчатые и брюхоногие моллюски. Локально они представляют собой нарастание серпулоидов, изолированных трубок и/или образованных ими колоний. Отмечается хорошая стратификация по видимому составу.

ЛФТ-2: Желвакообразный известняк структурно представлен вакстоуном и пакстоуном. Подобные прослои мощностью 10-20 см имеют субпараллельное переслаивание. Представлены многочисленными обломками раковин, главным образом двустворчатых и брюхоногих моллюсков с малым содержанием пирита.

ЛФТ-3: Волнистый известняк характерен для верхней части пачки Пиче. В породах наблюдается нерегулярное и волнистое переслаивание с частотой 10-30 см, свойственно наличие микростилолитов и стилолитов.

ЛФТ-4: Лалинарный известняк состоит из интервала мадстоуна с тонкой слоистостью (слоистый вид). Фаунистические осадки представлены аммонитами. Отмечается наличие включений известковой гальки, очень округлых, с диаметром $20-30 \mathrm{~cm}$

ЛФТ-5: Дололитовый известняк имеет зернистую структуру частиц илового размера, хорошо сортированных и окатанных, с отчетливой слоистостью. Контакты поверхностей разнообразны. Некоторые интервалы, особенно в направлении кровли пачки Мачикес, имеют маленькие прожилки, заполненные нерастворимым материалом. На некоторых участках встречается фауна аммонитов.

ЛФТ-6: Аргиллит/алевролит. Литофация сложена, преимущественно, глинистым материалом с незначительным количеством кварца. Для пород характерна тонкая слоистость. Выделяются массивные тонкослоистые разности без следов биотурбации с непрерывной и прерывистой слоистостью.

Диагностика микрофаций проводилась на основе анализа окаменелостей и оценке структурных компонентов (как скелетных, так и нескелетных), цемента и матрицы, что позволило выделить четырнадцать типов микрофаций (МФТ). Интерпретируемые фации делятся на три фациальные ассоциации: 1 - внутренний склон; 2 - средний склон; 3 - наружный склон осадочного бассейна.

\section{Ассоциация микрофаций для внутреннего склона}

Отложения микрофаций включают микрокристаллические доломиты, мадстоун и вакстоун (флаутстоун), двустворчатых моллюсков с гастроподами, вакстоун-пакстоун биокластический с преобладанием моллюсков. Широкое распространение имеют зерна с микритовыми покрытиями, большинство из которых несут признаки биоэрозии.
МФТ-1: микрокристаллический дололит. Представлен отчетливо зональными кристаллами доломита (темнее в центре и с прозрачными краями). Кристаллы являются идиоморфными ромбоэдрами. Кальциты с низким содержанием железа не доломотизированы. В первичной структуре иногда сохраняются остатки моллюсков и остракод. В тонких прослоях отмечаются следы органического вещества. Железистые минералы имеют широкое распространение. Пирит и фосфаты встречаются редко. Пористость, образованная в результате растворения кристаллов доломита, в определённых участках достигает $15 \%$, но чаще не превышает $5 \%$.

Этот тип микрофации характерен для сублиторали и литорали с проявлением волновой деятельности [24], где интенсивная доломитизация обычно происходит во время ранней стадии диагенеза [27].

МФТ-2: мадстоун/вакстоун с матрицей дололитизации. Микрофация состоит из иловой карбонатной породы с матрицей доломитизации. Ромбоэдрические кристаллы ( 0,2 мм) варьируют в пределах 5-10 и до $30 \%$. Доломитизация проявляется в виде пятен или распространяется в матрице. Биокласты, предположительно, состоят из моллюсков, брахиоподов и иглокожих и составляют примерно $20 \%$. Отмечается фосфатизация отдельных фрагментов и локальное окварцевание. Иловый характер этой микрофации и появление фрагментов морских беспозвоночных отражает осадконакопления в условиях приливно-отливной зоны спокойных вод.

МФТ-3: аргиллит/алевролит. Породы темносерого, коричневого или зеленовато-серого цвета представлены глинистым материалом, с незначительной примесью кварца илового размера и карбонатного вещества. Присутствует нерастворимый материал (чаще глины и углеводороды). Эти микрофации относятся к ЛТФ-6, которая представлена тонкими, массивными прослоями непрерывного или прерывисто-параллельного прослеживания по разрезу. Наиболее вероятной обстановкой седиментации отложений может быть приливно-отливная равнина.

МФТ-4: мадстоун с включенияли двустворчаmых лоллюсков. Характеризуется наличием в основной массе породы удлиненных и линзовидных прослоев светлого, серовато- и темно-коричневого известняка и фрагментированных скелетов беспозвоночных (до 10 \%), представленных брахиоподами, двустворчатыми и брюхоногими моллюсками, по раковинам отмечается пиритизация и окварцевание. Обилие известкового ила, очевидное отсутствие текстур волочения и фаунистические остатки указывают на формирование отложений в условиях низкоэнергетической подводной среды, вероятно, в условиях приливной зоны с пологим наклоном дна.

МФТ-5: ладстоун с пелоидали. Отложения соответствуют интервалу в пачке Пиче, для которого 
характерны коричнево-серые иловые карбонатные породы с пелоидами ( 0,39 мм). Отмечается хорошая окатанность и сортировка гранул, обилие пелоидов, сцементированных илом, что указывает на зону отложения с ограниченным доступом кислорода, вероятно, в пределах лагуны.

МФТ-6: вакстоун (флаутстоун) двустворчатых и брюхоногих моллюсков. Содержит разделенные, отшлифованные фрагменты раковин с истертыми оболочками (>6 мм) и хорошей окатанностью, главным образом представленные двустворчатыми и брюхоногими моллюсками. Фрагменты скелета с отверстиями являются редкими. Матрица состоит из микритов. Локально наблюдаются стилолитовые швы. Фосфаты и железистые минералы встречаются редко. В обнажении первичная седиментационная структура не определяется. Интерпретация условий седиментациии рассматриваемых отложений неоднозначна. Смесь известкового ила, ассоциация окаменелостей и отсутствие осадочных текстур указывают на осадконакопление рассматриваемой микрофации в условиях мелководья при слабой волновой деятельности. Однако вариации в разделенных фрагментированных истертых моллюсках указывают на возможность транспортировки фрагментов в среде с высокой энергией, например, течений или волн, вызванных штормами, что может быть связано с сублиторальной морской средой, защищенной лагунами во внутренней части склона.

МФТ-7: биокластовые вакстоун-пакстоун с преобладаниел моллюсков. Микрофация представлена илистыми и зернистыми известняки с обильными обломками моллюсков (> $45 \%$ ), главным образом двустворчатых, реже гастропод, остракод и иглокожих. Раковины претерпели биогенетические изменения (например, микритизация, наличие следов воздействия на осадок микроорганизмов и др.), растворение и минеральное новообразование (формирование агрегатов друз). В некоторых биокластических массивах отмечается относительно одинаковое заполнение пор. Присутствуют железистые минералы и фосфаты. Локально фиксируется пиритизация пород, окварцевание и интракластеризация. Интракласты указывают на предшествующую их образованию консолидацию породы, с указанием седиментации в условиях умеренной или высокой энергий. Фрагментарный характер скелетов беспозвоночных, возможно, связан со штормами. Эта микрофация может формироваться в обстановке внутреннего склона.

МФТ-8: мадстоун-вакстоун/вакстоун-пакстоун двустворчатых моллюсков и иглокожих $c$ бентосныли форалиниферали. Эта буровато-коричневый иловая микрофация представлена в основном двустворчатыми и брюхоногими моллюсками, иглокожими и, в некоторой пропорции, местными обитателями - бентосными фораминиферами и серпулоидами. Иловый известняк содержит остатки игл губок. Части кремнистых игл замещены пиритом. В большом количество присут- ствуют железистые минералы. Эти микрофации относятся к ЛФТ-2. Наличие донной фауны характерно для приливно-отливной зоны или приливной зоны в среде лагуны с хорошей циркуляцией воды.

\section{Ассоциация микрофаций среднего склона}

Определенные микрофации включают пакстоун двустворчатых моллюсков и иглокожих, грейнстоун иглокожих и кортоиды. В этих микрофациях очень распространены эффекты уплотнения, микростилолиты, полиморфные превращения арагонита в кальцит, пиритизации пород и в целом переработка частиц.

МФТ-9: пакстоун пелоидов с иглокожили. Он характеризуется коричневыми известняками и в меньшей степени известковым илом. Пелоиды (0,36 мм) встречаются очень часто (30-50 \% ) с хорошей окатанностью и сортировкой. Скопления иглокожих и кортоиды довольно распространены $(10-30 \%)$. Большая часть биокластов обрастает каемками кальцитового вещества, особенно иглокожие.

Природа этих микрофаций и ассоциации с включениями иглокожих свидетельствуют о водной обстановке, возможно, внутренние бары в лагуне, где поверхность осадконакопления выше нормального волнового базиса, при переходе от внутреннего к среднему склону платформы.

МФТ-10: пакстоун двустворчатых моллюсков состоит из светло-серо-бурых известняков, с обилием раковин двустворчатых моллюсков, в основном с остракодами (>50\%). Преимущественно наблюдаются обломки, но встречаются целые раковины с признаками растворения. Размер раковин может варьировать от нескольких миллиметров до 4 см в длину. Внутренние полости зацементированы или заполненны иловым карбонатным материалом. В этих микрофациях очень распространены эффекты уплотнения и микростилолиты (обычно заполненные нерастворимым материалом). Трещины более одного миллиметра имеют широкое распространение. Как правило, они заполнены кальцитом со следами растворения. В большом количестве присутствуют железистые минералы. Эти микрофации были интерпретированы [10] как биострома двустворчатых моллюсков в области среднего склона.

МФТ-11: пакстоун иглокожих и кортоиды состоят из известняков с небольшим количеством известкового ила, с преобладанием иглокожих и кортоидов (в основном конструктивных), и в меньшей пропорции интракластов ( $<2 \mathrm{mм})$, моллюсков (гастропод) и остракод. Пирит, глауконит и железистые минералы очень распространены в виде частиц или рассеяны в матрице. Наблюдается и частичная доломитизация и доломитизация биокластов. Большинство иглокожих с фрагментарным обрастанием кальцита по периферии выделений. Локально фиксируется образец с большим скоплением иглокожих. Пористость превышает $5 \%$. 
Низкое содержание микритового ила, ассоциация с интракластами, обломки иглокожих, моллюсков и переработанные биокласты указывают на условия формирования пород с энергией от умеренной до высокой, где поток воды становится турбулентным. Это может соответствовать условиям седиментации внутреннего бара лагуны, около и выше нормы волнового базиса, в обстановке среднего склона платформы.

\section{Ассоциация микрофаций для наружного склона бассейна}

Обнаруженные микрофации представлены мадстоун-вакстоуном с пелагическим планктоном фораминифер. В целом отсутствие осадочных текстур, связанных с течениями и волнами, свидетельствует об отложении этих микрофаций под воздействием гемипелагических и пелагических процессов.

МФТ-12: мадстоун-вакстоун с пелагическил планктоном форалинифер. Соответствует известняковому илу с тонкими включениями битума. Под обычным светом видна параллельная слоистость. Прослои слагают планктонные животные и окаменелости открытого моря (например, аммонитов). В пелагических глинах, а также в скелетных частицах распространен фосфатный материал. Пористость $(<1 \%)$ представлена микротрещинами. Преобладание пелагических мадстоунов с различным количеством планктонных микрофоссилий и нектонных окаменелостей указывает на глубоководную седиментацию, а наличие плоскопараллельной слоистости - на отложение осадков ниже базиса штормовых волн на глубинах более 100 м, в пределах наружного склона бассейна.

МФТ-13: вакстоун кальиисферы. Относится к пачке Пиче и состоит из микрофоссилий сферической формы, часто указывая на известняковые стены в микритовой матрице с нерастворимым материалом. Характерна параллельная слоистость. Кальцисферы, относящиеся к мезозою, связаны с открытой морской средой, в то время как домезозойские ограничиваются мелководной средой [24]. Наличие многочисленных кальцисфер, ассоциация с органическим веществом и параллельная слоистость предполагает формирование пород в глубокой и/или дистальной олигофотической зоне на наружнем склоне бассейна.

МФТ-14: мадстоун-вакстоун с нектонной фауной. Выделена в пачке Пиче и включает известняки с обломками гастропод, остракод, иглокожих и в меньшей степени нектонных окаменелостей (например, аммонитов). В некоторых фрагментах иглокожих присутствуют фосфатизированные остатки и пирит. Локально кристаллы доломита распространены в матрице. Эти микрофации относится к ЛФТ-3, где на отметке 200,43 м была найдена аммонитовая фауна (5 cм), свидетельствующая об условиях седиментации ниже штормового базиса в пределах наружного склона бассейна.
Таблица 1. Соотношение осадочных лито- и микрофащий формаиии Апон Группы Коголло, западной части бассейна Маракайбо

Table 1. Relation of sedimentary litho-microfacies of the Apón Formation of the Cogollo Group, western region of the Maracaibo Basin

\begin{tabular}{|c|c|}
\hline $\begin{array}{c}\text { Литофации (ЛФТ) } \\
\text { Lithofacies } \\
\end{array}$ & $\begin{array}{c}\text { Микрофации (МФТ) } \\
\text { Microfacies } \\
\end{array}$ \\
\hline $\begin{array}{l}\text { ЛФТ-1: } \\
\text { Массивный известняк } \\
\text { Massive limestones }\end{array}$ & $\begin{array}{l}\text { МФТ-7: биокластовые вакстоун-пакстоун с } \\
\text { преобладанием моллюсков } \\
\text { wackestone-packstone of mollusks } \\
\text { МФТ-9: пакстоун пелоидов с иглокожими } \\
\text { packstone of peloids and sponge spicules } \\
\text { МФТ-11: пакстоун иглокожих и кортоиды } \\
\text { packstone of sponge spicules and cortoids }\end{array}$ \\
\hline $\begin{array}{l}\text { ЛФТ-2: } \\
\text { Желвакообразный } \\
\text { известняк } \\
\text { Nodular limestones }\end{array}$ & $\begin{array}{l}\text { МФТ-4: мадстоун с включениями двуствор- } \\
\text { чатых моллюсков } \\
\text { mudstone of bivalves } \\
\text { МФТ-6: вакстоун (флаутстоун) двустворча- } \\
\text { тых и брюхоногих моллюсков } \\
\text { wackestone (floatstone) of bivalves } \\
\text { and gastropods } \\
\text { МФТ-8: мадстоун-вакстоун/вакстоун-пак- } \\
\text { стоун двустворчатых моллюсков и иглоко- } \\
\text { жих с бентосными фораминиферами } \\
\text { mudstone-wackestone/wackestone-расkstone } \\
\text { оf bivalves, sponges spicules and benthic fora- } \\
\text { minifers } \\
\text { МФТ-10: пакстоун двустворчатых моллюсков } \\
\text { расkstone of bivalves }\end{array}$ \\
\hline $\begin{array}{l}\text { ЛФТ-3: } \\
\text { Волнистый известняк } \\
\text { Wavy limestones }\end{array}$ & $\begin{array}{l}\text { МФТ-2: мадстоун/вакстоун с матрицей доло- } \\
\text { митизации } \\
\text { mudstone wackestone with dolomitized matrix } \\
\text { МФТ-5: мадстоун с пелоидами } \\
\text { mudstone with peloids } \\
\text { МФТ-13: вакстоун кальцисферы } \\
\text { wackestone of calcispheres }\end{array}$ \\
\hline $\begin{array}{l}\text { ЛФТ-4: } \\
\text { Ламинарный } \\
\text { известняк } \\
\text { Laminar limestones }\end{array}$ & $\begin{array}{l}\text { МФТ-12: мадстоун-вакстоун с пелагическим } \\
\text { планктоном фораминифер } \\
\text { mudstone-wackestone pelagic } \\
\text { with planktonic foraminifera } \\
\text { МФТ-14: мадстоун-вакстоун с нектонной } \\
\text { фаyной } \\
\text { mudstone-wackestone with nektonic fauna }\end{array}$ \\
\hline $\begin{array}{l}\text { ЛФТ-5: } \\
\text { Доломитовый } \\
\text { известняк } \\
\text { Dolomitic limestones }\end{array}$ & $\begin{array}{l}\text { МФТ-1: микрокристаллический доломит } \\
\text { microcrystalline dolomite }\end{array}$ \\
\hline \begin{tabular}{l|} 
ЛФТ-6: \\
Аргиллит/алевролит \\
Claystone/siltstone \\
\end{tabular} & $\begin{array}{l}\text { МФТ-3: аргиллит/алевролит } \\
\text { claystone- siltstone }\end{array}$ \\
\hline
\end{tabular}

\section{Обстановки осадконакопления}

Карбонатная последовательность нижней группы Коголло представляет собой совокупность осадочных пород, накопленных на полого наклонном рельефе вдоль континентальной окраины северо-запада Южной Америки [13, 28-30]. Ассоциация микрофаций и органическая составляющая осадка, включая его многообразие и тафономический характер, предполагает, что формирование толщи происходило преимущественно в условиях мелководной платформы при непрерывном воздействии волновых процессов. Согласно работе [10], отсутствие отложений гравитационных потоков 

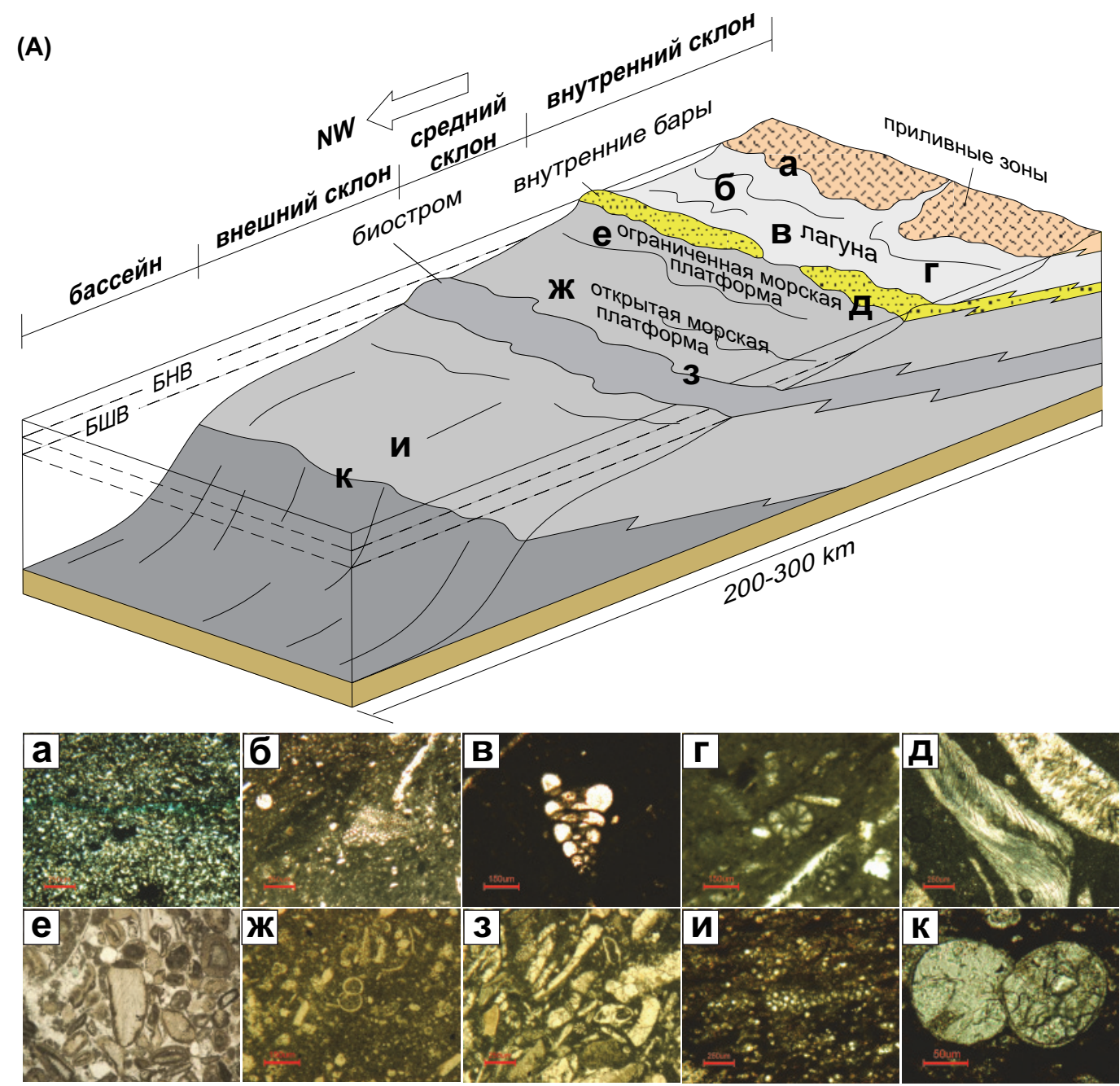

(Б)
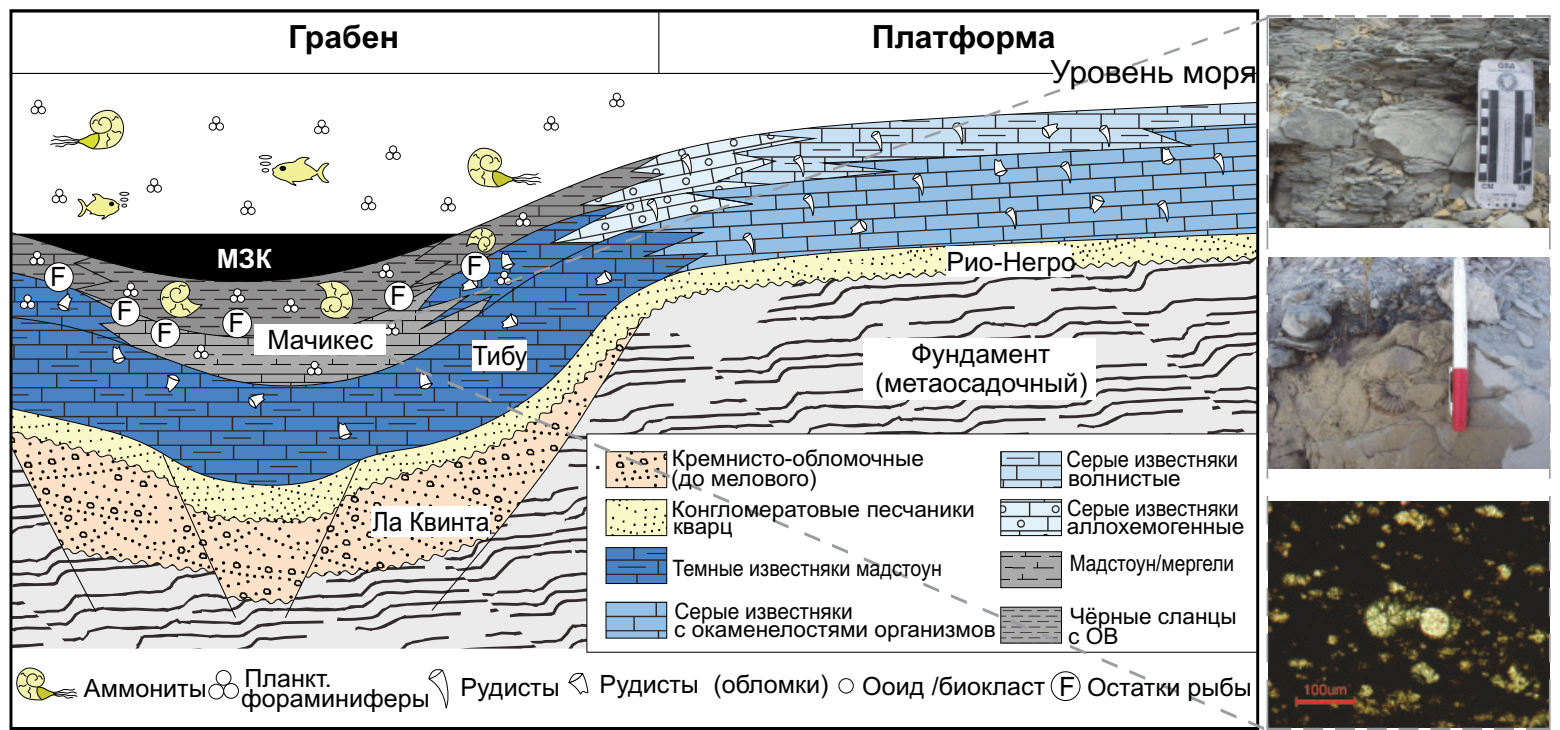

Рис. 2. (А) Идеализированная модель для обстановки осадконакопления в середине мелового периода склона Маракайбо и (Б) схелатическая модель пачки Мачикес в зоне грабена

Fig. 2. (A) Idealized model for depositional environment in the mid-Cretaceous Maracaibo ramp and (B) diagrammatic model of the Mbr. Machiques in graben zones 
свидетельствует о формировании осадков в условиях, при которых угол наклона поверхности напластования составляет не более $3^{\circ}$.

В результате выполненной систематизации изученные микрофации, представляющие различные седиментационные субобстановки, были соотнесены по фациальным зонам. Основой проведённого распределения послужила схема, предложенная в работе [25], где для карбонатных склонов выделяется четыре зоны осадконакопления, соответствующие: внутреннему склону (1), среднему склону (2), внешнему склону (3) и открытому бассейну (4).

Учитывая местоположение изучаемого разреза в пределах грабенной зоны Мачикес, можно сделать вывод о формировании формации Апон в более глубоководных условиях и в восстановительной обстановки седиментации
Последовательность диагенетических преобразований формации Апон

Наиболее важным фактором в оценке потенциала нефтяного месторождения в карбонатных породах является анализ влияния диагенеза на пористость коллектора. Во многих уникальных нефтяных месторождениях, выявленных в карбонатных толщах, диагенез играет важную роль в повышении их пористости. В табл. 2 представлена последовательность диагенетических преобразований, выявленных в породах формации Апон при изучении.

Диагенетическая эволюция карбонатных пород представленного разреза может быть разделена на три этапа:

Первый этап - ранний диагенез или сингенетический, проявляющийся в осадочной среде при неглубоком захоронении, характеризующийся поч-

Таблица 2. Последовательность парагенетических преобразований в породах формации Апон

Table 2. Paragenetic sequence in the rocks of the Apón Formation

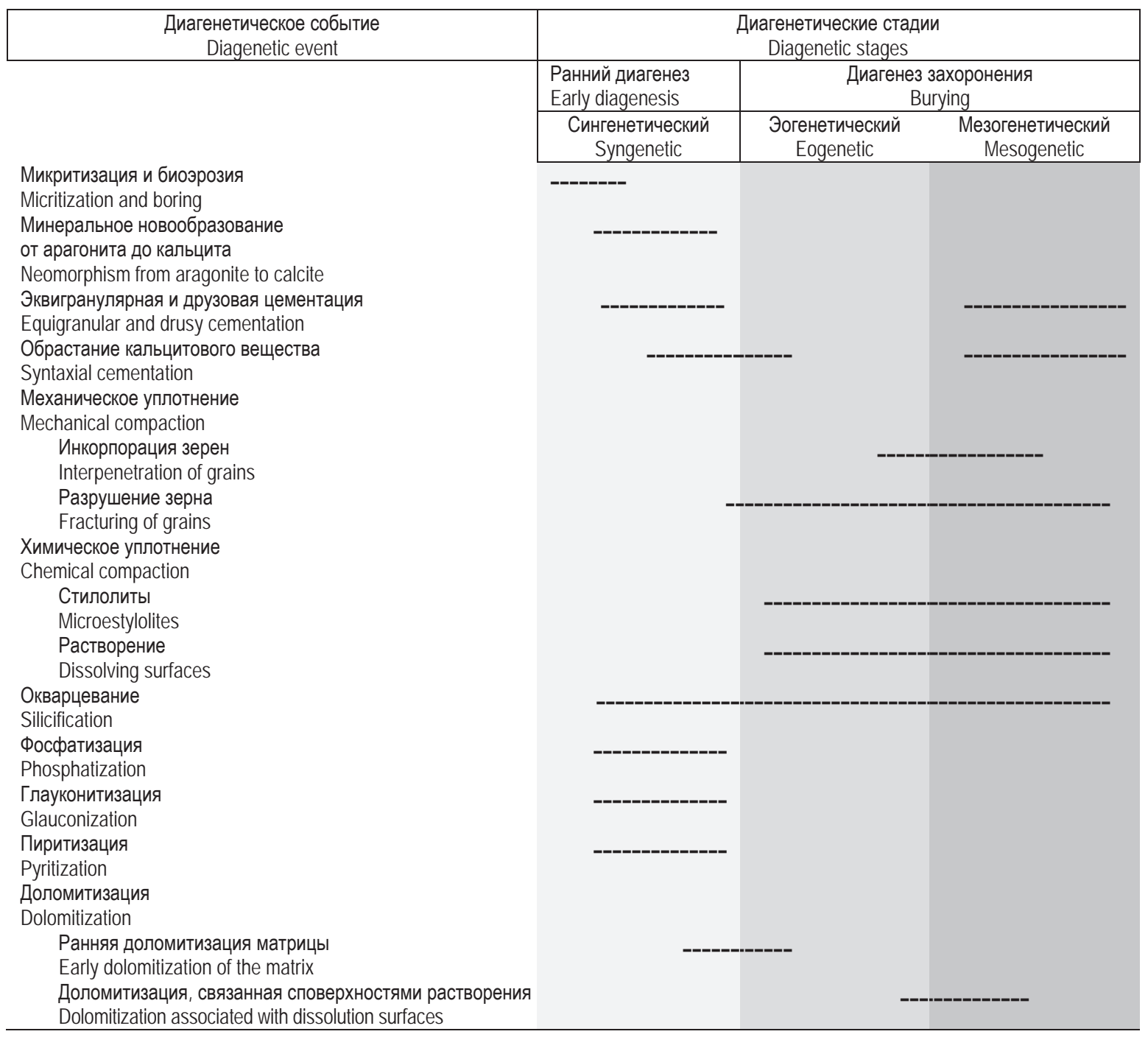


ти одновременными изменениями (например, селективным растворением и повторным осаждением, биоэрозией, микритизацией), цементацией, глауконитизацией и фосфатизацией.

Второй этап - диагенез промежуточного захоронения или эогенетический (метеорный) (например, осаждение минералов в растворе или растворение карбонатного вещества).

Третий этап - диагенез глубокого захоронения или мезогенетический (например, цементация, механическое уплотнение, стилолитизация и трещинообразование).

Главные диагенетические процессы, которые, вероятно, повлияли на образование открытой пористости - это доломитизация, обусловившая образование поверхностей растворения, особенно в биокластической фации, трещинообразование (мезотрещины в фации без или с небольшим содержанием карбонатного ила, микротрещины в илистых фациях) и стилолитизация. Процессы снижения пористости обусловлены цементацией пор и трещин, а также механическим уплотнением осадка. Стилолитизация, как правило, уничтожает пористость, но во многих случаях образуется вторичная пористость.

Доломитизация в последовательности пород формации Апон варьируется от общей до избирательной. Последняя позволяет определять первичную структуру породы. На основе петрографических критериев и стратиграфического расположения доломиты данной последовательности можно рассматривать в качестве замещающего элемента, а их формирование, вероятно, произошло во время условий неглубоководных захоронений. Напротив, доломит, связанный с поверхностями растворения и образующий правильные ромбовидные кристаллы, приуроченные к зонам химического уплотнения - стилолитам, указывает на позднюю стадию захоронения.

В изучаемом обнажении в последовательности пород наблюдается обширная система трещин, распространенных под разными углами. Ширина этих трещин варьируется от нескольких миллиметров до пяти сантиметров. Большинство трещин выполнены, главным образом, кальцитом. Аналогичные закономерности развития отмечены и для стилолитов, заполненных нерастворимым материалом. Одни трещины и заполняющий их материал предшествовали развитию стилолитов и миграции углеводородов. Другие трещины образовались после стилолитов и были заполнены углеводородами.

Наиболее важными разновидностями пористости, обнаруженными в породах формации Апон, являются:

1) вторичная пористость за счёт выщелачивания остатков организмов в ракушечнике;

2) трещинная пористость;

3) внутрикристаллическая селективная пористость (формируется в результате растворения во внутренних областях доломитовых ромбов);

4) межзерновая пористость;

5) канальная (порово-пустотная) пористость - неселективная пористость, наблюдаемая по границам зерен доломита в верхней части изучаемого осадочного разреза.
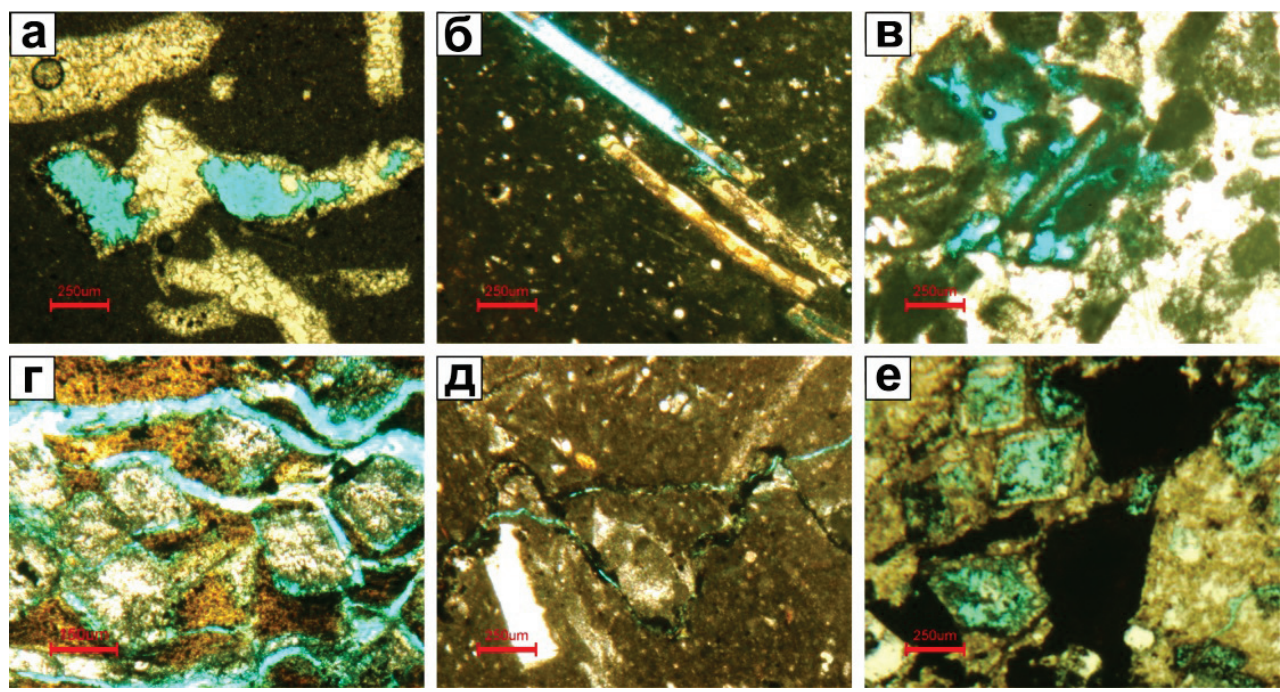

Pис. 3. Микрофотографии типов пористости отложений формации Апон: а) пачка Тибу: вторичная пористость за счёт выщелачи вания ракушечника (частично восстановленная кальцитовым цементом); б) пачка Пиче: вторичная пористость за счёт вы щелачивания ракушечника; в) пачка Пиче: межзерновая пористость; г) форлация Лижур: неселективная канальная пори стость; д) пачка Мачикес: стилолитовая пористость; е) пачка Пиче: внутрикристаллическая пористость. Фотографии шлифов без анализатора

Fig. 3. Types of porosity: a) Member Tibü- moldic porosity partially reduced by calcite cement; б) Member Piché - moldic porosity; в) Member Piché - intergranular porosity; 2) Formation Lisure - non-selective channel porosity developed perhaps by dissolution and pressure solution processes; d) Member Machiques - stylolitic porosity; e) Member Piché-intracrystalline porosity. Microfotographs using parallel Nicols 
Пористость рассматриваемой последовательности отложений не превышает $5 \%$, однако ближе к кровле, где отмечается доломитизация, она достигает $>10 \%$. Тем не менее, наблюдаемая пористость по разрезу изучаемой толщи недостаточна для формирования проницаемых пластов.

Океанические аноксидные события

Ранний мел был периодом с суперпарниковыми климатическими условиями и эпизодическими проявлениями океанических аноксидных событий. Предполагается, что быстрый приток вулканогенного $\mathrm{CO}_{2}$ в атмосферу вызвал парниковый эффект, что, в свою очередь, привело к повышению уровня океана [31]. Отложения, обогащённые органическим углеродом, формировались в периоды морских трансгрессий [9]. АОС раннего альба, обусловленные дефицитом кислорода в океанических водах, усилили накопление морских осадков, богатых органическим материалом, сформировав основные нефтематеринские породы мирового значения [32, 33].

Пачка Мачикес образовалась в результате быстрой и обширной трансгрессии, охватившей почти весь бассейн Маракайбо. По результатам анализа массового процентного содержания общего органического углерода (ООУ) образцов, собранных автором в поле (табл. 3), его значения варьируются от 0,52 до $13,49 \%$, что соответствует градации качества нефтематеринской породы от хорошего до превосходного, согласно [34].

Учитывая наличие в отложениях аммонитов Deshayesites аптского возраста [35], можно сделать вывод об океаническом аноксидном событии (AOC-1a) на мелководной платформе, в пределах которой в пачке Мачикес происходила генерация и миграция углеводородов. Вероятно, нефтяные месторождения формаций Рио-Негро (нижележащей) и Пиче (вышележащей) являются результатом этой миграции [9].

В наиболее приподнятой зоне пачки Пиче в обнажении есть доказательства проявления трансгрессии моря в виде наличия обильных остатков аммонитов и высокого значения гамма-каротажа.

Рассматриваемые отложения формировались в период проявления АОС-1б и характеризуются высокими значениями (до 13,49 \%) содержания органического углерода в пачке Пиче, что свидетельствует о значительном углеводородном потенциале изучаемых пород.

Выполненное автором изучение разреза карьера Цементос Катакумба С.А. выявило трансгрессивное несогласие между карбонатными отложениями формации Апон (пачка Пиче) и терригеннокарбонатной формацией Лижу, что не противоречит геологическому строению рассматриваемых формаций в бассейне Маракайбо.

Наблюдаемые высокие коллекторские свойства отложений кровли пачки Пикче и их нефтенасышенность позволяют сделать предположение, что углеводороды не обязательно были сгенерированы формацией Ла Луна. Возможно, их формирование было связано с обогащёнными органическим углеродом отложениями формации Апон [9].

Проведённые различными авторами исследования керна глубоких скважин бассейна Моракайбо с привлечением данных анализа ООУ, индекса водорода, температуры крекинга керогена (Tmax) и геохимического анализа позволяют считать пачки Мачикес и Пиче возможными нефтематеринскими породами [36, 37], способными генерировать углеводороды $[9,38,39]$.

Таблица 3. Образиы разреза. Результаты общего органического углерода

Table 3. Outcrop samples. Total organic carbon results

\begin{tabular}{|c|c|c|c|c|c|c|c|}
\hline \multirow[b]{2}{*}{ 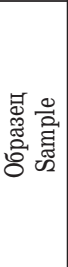 } & \multirow[b]{2}{*}{$\begin{array}{l}\text { Имя } \\
\text { Name }\end{array}$} & \multirow[b]{2}{*}{ 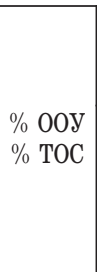 } & \multicolumn{3}{|c|}{$\begin{array}{c}\text { Статистическая } \\
\text { обработка } \\
\text { Statistical processing }\end{array}$} & \multirow[b]{2}{*}{$\begin{array}{c}\text { Член } \\
\text { Member }\end{array}$} & \multirow{2}{*}{ 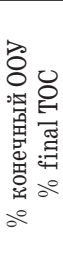 } \\
\hline & & & 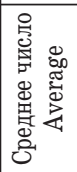 & $\sigma$ & 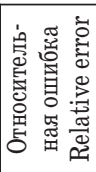 & & \\
\hline $\begin{array}{c}1 \\
1(R)\end{array}$ & $\begin{array}{l}\text { MI-AFL2-A } \\
\text { MI-AFL2-A } \\
\text { (R) }\end{array}$ & $\begin{array}{l}13,5070 \\
13,4740\end{array}$ & 13,49 & 0,02 & 0,17 & $\begin{array}{l}\text { Мачикес } \\
\text { Machiques }\end{array}$ & 13,49 \\
\hline $\begin{array}{c}2 \\
2(\mathrm{R})\end{array}$ & $\begin{array}{l}\text { MI-AFL4-A } \\
\text { MI-AFL4-A } \\
\text { (R) }\end{array}$ & $\begin{array}{l}17,7420 \\
17,7790\end{array}$ & 17,76 & 0,03 & 0,15 & \multirow{6}{*}{$\begin{array}{l}\text { Пиче } \\
\text { Piche }\end{array}$} & 17,76 \\
\hline $\begin{array}{c}3 \\
3(\mathrm{R})\end{array}$ & $\begin{array}{l}\text { MI-AFL4-B } \\
\text { MI-AFL4-B } \\
\quad(\mathrm{R})\end{array}$ & $\begin{array}{l}5,9226 \\
5,9425\end{array}$ & 5,93 & 0,01 & 0,24 & & 5,93 \\
\hline $\begin{array}{c}4 \\
4(\mathrm{R})\end{array}$ & $\begin{array}{l}\text { MI-AFL4-C } \\
\text { MI-AFL4-C } \\
\quad(\mathrm{R})\end{array}$ & $\begin{array}{l}8,0299 \\
8,0982\end{array}$ & 8,06 & 0,05 & 0,60 & & 8,06 \\
\hline $\begin{array}{c}5 \\
5(\mathrm{R})\end{array}$ & $\begin{array}{l}\text { MI-AFL4-D } \\
\text { MI-AFL4-D } \\
\quad(\mathrm{R})\end{array}$ & $\begin{array}{l}10,1750 \\
10,1890\end{array}$ & 10,18 & 0,01 & 0,10 & & 10,18 \\
\hline $\begin{array}{c}6 \\
6(\mathrm{R})\end{array}$ & $\begin{array}{l}\text { MI-AFL4-E } \\
\text { MI-AFL4-E } \\
\quad(\mathrm{R})\end{array}$ & \begin{tabular}{|l|}
8,1733 \\
8,1649
\end{tabular} & 8,17 & 0,01 & 0,07 & & 8,17 \\
\hline $\begin{array}{c}7 \\
7(\mathrm{R})\end{array}$ & $\begin{array}{l}\text { MI-AFL4-F } \\
\text { MI-AFL4-F } \\
\quad(\mathrm{R})\end{array}$ & $\begin{array}{l}5,4601 \\
5,4537\end{array}$ & 5,46 & 0,00 & 0,08 & & 5,46 \\
\hline $\begin{array}{c}8 \\
8(\mathrm{R})\end{array}$ & $\begin{array}{c}\text { MI-AFL2-113 } \\
\text { MI-AFL2-113 } \\
\text { (R) }\end{array}$ & $\begin{array}{l}0,6775 \\
0,7025\end{array}$ & 0,69 & 0,02 & 0,17 & $\begin{array}{l}\text { Тибу } \\
\text { Tibu }\end{array}$ & 0,69 \\
\hline $\begin{array}{c}9 \\
9(\mathrm{R})\end{array}$ & $\begin{array}{l}\text { MI-AFL3-140 } \\
\text { MI-AFL3-140 } \\
\text { (R) }\end{array}$ & $\begin{array}{l}0,5092 \\
0,5308\end{array}$ & 0,52 & 0,02 & 0,17 & \multirow{3}{*}{$\begin{array}{l}\text { Мачикес } \\
\text { Machiques }\end{array}$} & 0,52 \\
\hline $\begin{array}{c}10 \\
10(R)\end{array}$ & $\begin{array}{l}\text { MI-AFL3-156 } \\
\text { MI-AFL3-156 } \\
\text { (R) }\end{array}$ & $\begin{array}{l}3,6245 \\
3,5755\end{array}$ & 3,60 & 0,05 & 0,60 & & 3,60 \\
\hline $\begin{array}{c}11 \\
11(\mathrm{R})\end{array}$ & $\begin{array}{l}\text { MI-AFL3-169 } \\
\text { MI-AFL3-A169 } \\
\text { (R) }\end{array}$ & $\begin{array}{l}1,2879 \\
1,2921\end{array}$ & 1,29 & 0,00 & 0,08 & & 1,29 \\
\hline
\end{tabular}

ООУ: Общий органический углерод, ТОС: total organic carbon. $(R)$ : образеи, проанализированный в двух экзелплярах, $(R)$ : sample, analyzed in duplictae. Относительная ошибка $<5 \%$, relative error $<5 \%$.

\section{Среднемеловой стратиграфический разрез западной Венесуэлы}

В процессе изучения представленная последовательность напластования отложений среднего мела в обнажениях участка Сьерра-де-Периджа была сопоставлена с результатами стратиграфиче- 


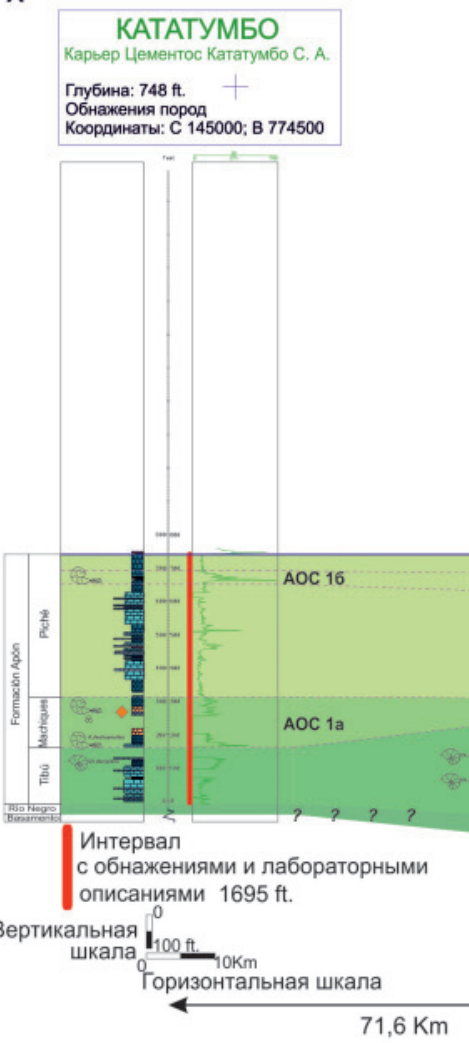

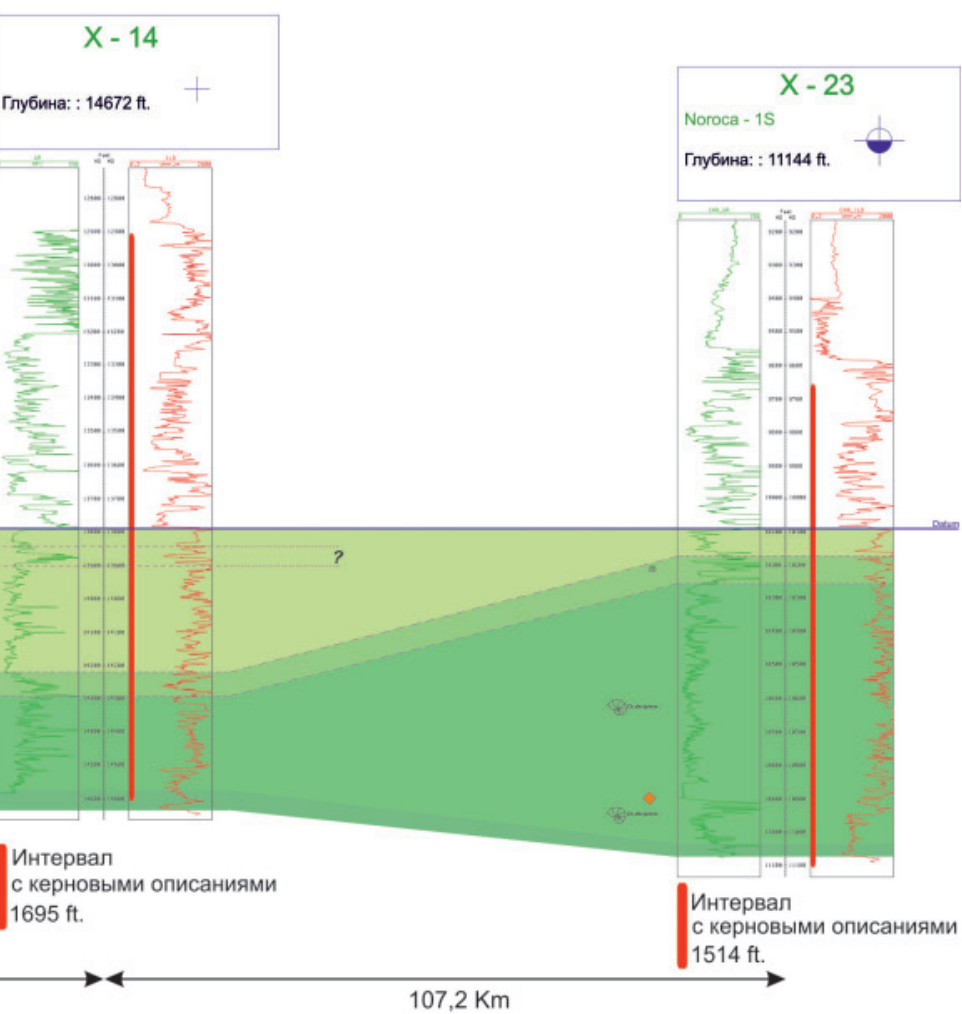

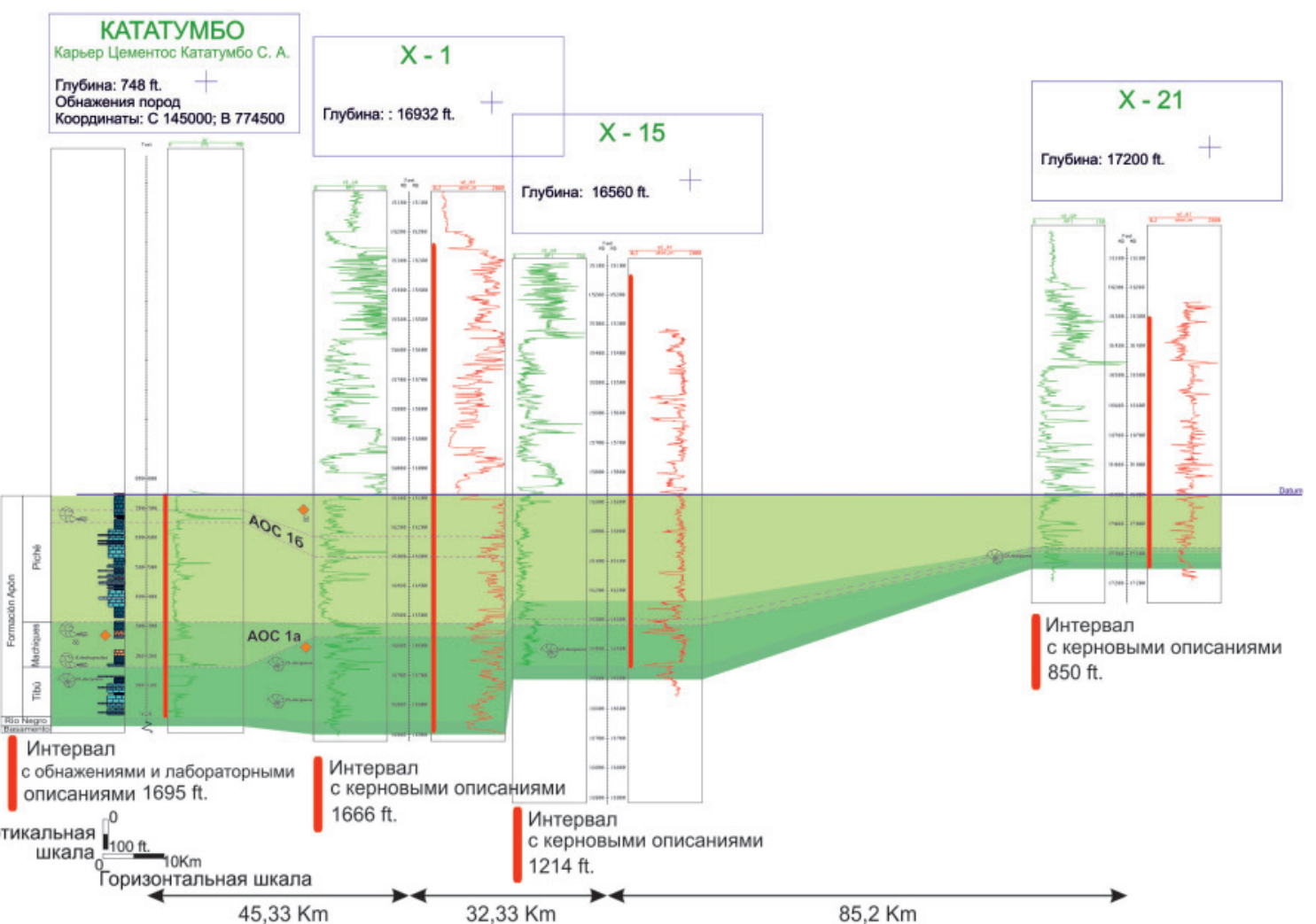

Pис. 4. Корреляция пород в обнажении Цементос Кататулбо С.А. с нефтяныли скважинами по гамла-каротажу в западном бассейне Маракайбо на основе выделения маркирующих горизонтов (Разрезы А-А', Б-Б’ соответствуют обозначению на рис. 1 )

Fig. 4. Correlation of the outcrop section with oil wells by gamma ray log in western Maracaibo basin on the basis of marking horizons (Cuts A$A^{\prime}$, b-b'correspond to Fig. 1) 
ского расчленения аналогичного осадочного комплекса в скважинах X-1, X-15, X-21, X-14 и X-23 (рис. 4).

На рассматриваемом участке формация Апон ограничена в подошве контактом между континентальными (формация Рио-Негро) и морскими (пачка Тибу) отложениями. Дальнейшее повышение относительного уровня моря способствовало более глубоководной седиментации.

Средняя часть формации Апон, представленная пачкой Мачикес, формировалась в АОС-1а. Образование пачки соответствует максимальной фазе развития трансгрессии, что хорошо отражается повышенными значениями гамма-каротажа.

Последующая регрессия морского бассейна способствовала усилению интенсивности осаждения карбонатов и перемещению береговой линии, в результате чего сформировалась типичная, в основном мелководная, внутренняя карбонатная платформы, что согласуется с литологическим строением пачки Пиче.

Осадочная последовательность продолжается накоплением пелагических известняков, сформированных в процессе быстрой трансгрессии. Пелагические фации, богатые органическими веществами, были отложены в результате AOC-1б. Впоследствии карбонатная платформа расширяется и уступает место регрессии, что согласуется с условиями отложения формации Лижур.

\section{Выводы}

Проведённые исследования показали, что осадочный разрез апт-альба характеризуется шестью литофациями и 14 микрофациями. Ископаемые известняки представлены ваккитом и пакстоуном двустворчатых моллюсков и устриц, иглокожие с бентовыми фораминиферами типичны для пачки Тибу. Пелагические известняки и структурные аргиллиты, с планктонными фораминиферами, остатками слоев аммонитов и доломитов слагают пачку Мачикес. Известняки, представленные аргиллитом с моллюсками и бентосными фораминиферами, ваккитом и пакстоуном, в которых доминируют моллюски, и пакстоун иглокожих, кортоидов и пелоидов типичны для пачки Пиче.

Фации и связанные с ними условия седиментации указывают на то, что апт-альбские породы в бассейне Маракайбо отлагались на склоне карбонатной платформы. Визуально пористые типы фа-

\section{СПИСОК ЛИТЕРАТУРЫ}

1. Schlanger S.O., Jenkyns H.C. Cretaceous oceanic anoxic events: causes and consequences // Geologie en Mijnbouw. - 1976. V. 55. - P. 179-184. URL: https://www.researchgate.net/publication/27710997_Cretaceous_0ceanic_Anoxic_Events_Causes_and_consequences (дата обращения 09.10.2018).

2. Marine primary producer community during the mid-Cretaceous oceanic anoxic events (OAEs) 1a, $1 \mathrm{~b}$ and $1 \mathrm{~d}$ in the Vocontian Basin (SE France) evaluated from triaromatic steroids in sediments / Takuto Ando, Ken Sawada, Kazuki Okano, Reishi Takashima, Hi- ций ограничены осадками высокоэнергетической обстановки (например, скелетным пакстоуном), тогда как отложения фаций внутреннего и внешнего склонов обычно уплотнены.

Таким образом, проведённое автором изучение стратиграфического разреза показывает историю преобразования пород, которое включает три стадии: сингенетическую (например, селективное растворение, биоэрозия и/или микритизация); эогенетическую (растворение или осаждение минералов в растворе); мезогенетическую (например, уплотнение, взаимопроникновение зерен, стилолитизация, растворение, минеральное новообразование, обрастание кальцитового вещества по периферии фрагментов).

Пористость рассматриваемого комплекса пород в целом не превышает $5 \%$, за исключением некоторых доломитизированных интервалов. На основании петрографических критериев и стратиграфической приуроченности доломитовые интервалы являются результатом ранних и/или субповерхностных диагенетических процессов.

Проведенные автором литолого-петрографические исследования и анализ содержания органического углерода в породах обнажения карьера Цементос Кататумбо С.А. позволили выделить два стратиграфических интервала (пачка Мачикес и Пиче), обогащённых органическим веществом, что означает потенциальную возможность отнести их к нефтематеринским и нефтегенерирующим толщам. Формирование этих отложений было связано с этапами AOC-1a и AOC-1б, для которых были характерны восстановительные условия седиментации. Наличие в разрезе обнажения этих нефтепродуцирующих отложений свидетельствует о широком площадном развитии формации Апон. Это, в свою очередь, существенно расширяет поисковые работы на нефть и газ в пределах континентальной равнины между озером Маракайбо и складчатой системой Анд, а также в северной акватории морского побережья Венесуэлы.

Результаты, представленные в этой статье, являются частью научно-исследовательского проекта, который был проведен в сотрудничестве с исследователяли проекта PGO Golfo de Venezuela. Aвтор выражает благодарность сотрудникам компании PDVSA Exploration and Reservoir Integrated Studies - Puerto La Cruz, PDVSA Exploration-Maracaibo u PDVSA Geological Laboratory El ChaurePuerto La Cruz за поддержку при работе над исследовательскил проектол.

roshi Nishi // Organic Geochemistry. - 2017. - V. 106. P. 13-24. URL: https://www.sciencedirect.com/science/article/pii/S0146638017300335 (дата обращения 02.04.2018).

3. Stratigraphy, geochemistry, and paleoceanography of organiccarbon rich Cretaceous sequences / M.A. Arthur, H.C. Jenkyns, H.J. Brumsack, S.O. Schlanger // Cretaceous Resources, Events and Rhythms / Eds. R.N. Ginsburg, B. Beaudoin. - Dordrecht: Kluwer Academic, 1990. - V. 304. - P. 75-119. URL: https://www.researchgate.net/publication/230889733 Stratigraphy_Geochemistry_and_Paleoceanography_of_Organic_Carbon-Rich_Cretaceous_Sequences (дата обращения 13.03.2018). 
4. Gaona-Narvaez T., Maurrasse F.J.M.R., Etayo-Serna F. Geochemistry, palaeoenvironments and timing of Aptian organic-rich beds of the Paja Formation (Curití, Eastern Cordillera, Colombia). - London: Geological Society, 2013. - Special Publications. - V. 382. URL: https://core.ac.uk/download/pdf/ 46952723.pdf (дата обращения 02.04.2018).

5. Méndez J., Baquero M. Sedimentación del Grupo Cogollo. Facies, Reservorios, Porosidad y Niveles de Roca Madre. Sistema Petrolero. - Maracaibo: PDVSA Exploración, 2008. - 222 p.

6. Petroleum Distribution Characteristics of the Americas and the Exploration Prospect Analysis / Hao Qingqing, Li Lintao, Zuo Yinhui, Chen Weijun, Wu Lei, Yi Junjie // Acta Geologica Sinica (English Edition). - 2018. - V. 92. - P. 378-393. URL: https://onlinelibrary.wiley.com/doi/pdf/10.1111/ 1755-6724.13512 (дата обращения 04.04.2018).

7. Hydrogeochemical characterization of oilfield waters from southeast Maracaibo Basin (Venezuela): Diagenetic effects on chemical and isotopic composition / T. Boschetti, B. Angulo, F. Cabrera, J. Vasquez, R. Montero // Marine and Petroleum Geology. - 2016. - V. 73. - P. 228-248. URL: https://www.sciencedirect.com/science/article/pii/S0264817216300435 (дата обращения 03.04.2018)

8. Liborius-Parada A., Slatt R.M. Geological Characterization of La Luna Formation as an Unconventional Resource in Lago De Maracaibo Basin, Venezuela // SPE/AAPG/SEG Unconventional Resources Technology Conference. - San Antonio, Texas, USA, 2016. - P. 1-20 URL: https://www.onepetro.org/conference-paper/URTEC-2461968-MS (дата обращения 05.04.2018).

9. The Cogollo Group and the oceanic anoxic events 1a and 1b, Maracaibo basin, Venezuela / J.A. Méndez, J. Méndez, D. Reyes, R. Whilchy // Brazilian Journal of Geology. - 2015. - V. 45. P. 41-61. URL: https://www.researchgate.net/publication/ 282743319 The Cogollo Group and the oceanic anoxic_events_1a_and_1b_Maracaibo_basin_Venezuela (дата обращения 05. $04 . \overline{2} 018 \overline{)}$.

10. Geología Sedimentaria de la Sucesión Barremiense-Cenomaniense, Grupo Cogollo-Basal La Luna, en la Región Central de la Cuenca de Maracaibo / Pinto J., Ortega S., Medina C., León L., Oropeza H., Rodríguez I. - Caracas: PDVSA-Intevep, 2009. - 194 p.

11. Забанбарк А., Лобковский Л.И. Структурные черты и перспективы нефтегазоносности карибского региона / / Океанология. 2017. - T. 57. - № 5. - C. 799-814. URL: https://elibrary.ru/item.asp?id=30258158 (дата обращения 03.04.2018).

12. González C., Iturralde J., Picard X. Geología de Venezuela y sus Cuencas Petroliferas. - Caracas: Foninves, 1980. - V. 1. 1001 p. URL: https://es.scribd.com/doc/22828562/Geologia-deVenezuela-y-sus-Cuencas-Petroliferas-Parte-1-Gonzalez-de-Juana (дата обращения 21.02.2018).

13. Mann P., Escalona A., Castillo M. Regional geologic and tectonic setting of the Maracaibo supergiant basin, western Venezuela // AAPG Bulletin. - 2006. - V. 90. - № 4. - P. 445-477. URL: https://pubs.geoscienceworld.org/aapgbull/article-abstract/90/4/445/132738/regional-geologic-and-tectonic-settingof-the?redirectedFrom=fulltext (дата обращения 05.04.2012).

14. Stratigraphic synthesis of western Venezuela. Petroleum Basins of South America / F. Parnaud, Y. Gou, J.C. Pascual, M.A. Capello, I. Truskowski, H. Passalacqua // AAPG Memoir: Petroleum Basins of South America. - 1995. - V. 62. - P. 681-698. URL: https://pubs.geoscienceworld.org/books/book/1367/chapter/107170184/stratigraphic-synthesis-of-western-venezuela (дата обращения 26.05.2018).

15. Perla Field: The Largest Discovery Ever in Latin America V. Castillo, L. Benkovics, C. Cobos, D. Demuro, A. Franco // AAPG Special Volumes. Memoir 113: Giant Fields of the decade 2000-2010. - 2017. - P. 141-152. URL: http://archives.datapages.com/data/specpubs/memoir113/data/141_aapgsp2020141.htm (дата обращения 03.04.2018).
16. Bartok P., Reijers T., Juhasz I. Lower Cretaceous Cogollo Group, Maracaibo Basin, Venezuela: sedimentology, diagenesis, and petrophysics // AAPG Bulletin. - 1981. - V. 65 - - P. 1110-1134. URL: http://archives.datapages.com/data/bulletns/1980-81/da$\mathrm{ta} / \mathrm{pg} / 0065 / 0006 / 1100 / 1110 . \mathrm{htm}$ (дата обращения 14.03.2018).

17. Four-phase tectonostratigraphic development of the southern $\mathrm{Ca}$ ribbean / A.N. Eva, K. Burke, P. Mann, G. y Wadge // Marine and Petroleum Geology. - 1989. - V. 6. - P. 9-21. URL: https:// www.sciencedirect.com/science/article/pii/026481728990072X (дата обращения 05.04.2018).

18. Overview of the southeast Caribbean-South American plate boundary zone / M. Ostos, F. Yoris, H. Llallemant // Special Paper of the Geological Society of America // Caribbean-South American plate interactions, Venezuela / H.G. Avé Lallemant, V.B. Sisson. - 2005. - V. 394. - P. 53-89. URL: https://www.researchgate.net/publication/283942470 0verview of the southeast_Caribbean-South_American_plate_boundary_zone (дата обращения 05.04.2018).

19. Rod E., Maync W. Revision of Lower Cretaceous stratigraphy of Venezuela // AAPG Bulletin. - 1954. - V. 38. - № 2. P. 193-283. URL: https://pubs.geoscienceworld.org/aapgbull/ article-abstract/38/2/193/33988/revision-of-lower-cretaceousstratigraphy-of (дата обращения 05.04.2018).

20. Renz 0. Estratigrafía del Cretáceo en Venezuela Occidental // Boletin del Ministerio de Minas e Hidrocarburos. Venezuela. 1958. - V. 5. - № 10. - P. 3-48.

21. Birth and death of the Late Cretaceous «La Luna Sea», and origin of the Tres Esquinas phosphorites / R.N. Erlich, 0. Macsotay, A.J. Nederbragt, M.A. Lorente // Journal of South American Earth Sciences. - 2000. - V. 13. - P. 21-45. URL: https://www. sciencedirect.com/science/article/pii/S089598110000016X (дата обращения 01.06.2018).

22. Martínez R.J.I., Hernandez R. Evolution and drowning of the Late Cretaceous Venezuelan carbonate platform // Journal of South American Earth Sciences. - 1992. - V. 5. - P. 197-210. URL: https://www.sciencedirect.com/science/article/pii/ 089598119290038Z (дата обращения 01.06.2018).

23. Escalona A., Mann P. Sequence-stratigraphic analysis of Eocene clastic foreland basin deposits in central Lake Maracaibo using high-resolution well correlation and 3-D seismic data // AAPG Bulletin. - 2006. - V. 90. - P. 581-623. URL: https://pubs.geoscienceworld.org/aapgbull/article-abstract/90/4/581/ 132752 /sequence-stratigraphic-analysis-of-eocene-clastic?redirectedFrom=fulltext (дата обращения 05.04.2018).

24. Flügel E. Microfacies of Carbonate Rocks. Analysis, Interpretation and Application. Springer. - 2004. - 921 p. URL: https:// www. springer.com/us/book/9783662087268 (дата обращения 04.06.2018).

25. Burchette T.P., Wright P. Carbonate ramp depositional systems // Sedimentary Geology. - 1992. - V. 79. - P. 3-57. URL: https:// www.sciencedirect.com/science/article/pii/003707389290003A (дата обращения 02.07.2018).

26. Choquette P.W., Pray L.C. Geologic nomenclature and classification of porosity in sedimentary carbonates // AAPG Bulletin. 1970. - V. 54. - № 2. - P. 207-250. URL: http://archives.datapages.com/data/bulletns/1968-70/data/pg/0054/0002/0200/ 0207 .htm?doi=10.1306 \% 2F5D25C98B-16C1-11D7$8645000102 \mathrm{C} 1865 \mathrm{D}$ (дата обращения 02.07.2018).

27. Tucker M.E., Wright D. Carbonate sedimentology. - USA: Blackwell Science, 2004. - 482 p. URL: https://onlinelibrary.wiley.com/doi/10.1002/9781444314175.fmatter (дата обращения 02.07.2018).

28. Bartok P., Y Reijers T. Patrones depositacionales, diagénesis y evaluación de reservorios en el Grupo Cogollo, Cretáceo Inferior, Cuenca de Maracaibo. - Maracaibo: Maraven S.A. and Shell, 1979. $-28 \mathrm{p}$.

29. Bartok P., Reijers T., Juhasz I. Lower Cretaceous Cogollo Group, Maracaibo Basin, Venezuela: sedimentology, diagenesis, and pet- 
rophysics // AAPG Bulletin. - 1981. - V. 65 - P. 1110-1134. URL: http://archives.datapages.com/data/bulletns/1980-81/ $\mathrm{data} / \mathrm{pg} / 0065 / 0006 / 1100 / 1110 . \mathrm{htm}$ (дата обращения 14.03.2018).

30. Audemard F. Tectonics of western Venezuela. Ph.D. Thesis. Houston, Texas, USA, 1992. - 245 p. URL: https://scholarship.rice.edu/handle/1911/16556?show=full (дата обращения 14.03.2018)

31. Aptian and Albian atmospheric $\mathrm{CO}_{2}$ changes during oceanic anoxic events: evidence from fossil Ginkgo cuticles in Jilin Province, Northeast China / Y.W. Sun, X. Li, G. Zhao, H. Liu, Y. Zhang // Cretaceous Research. - 2016. - V. 62. - P. 130-141. URL: https://www.sciencedirect.com/science/article/pii/ S0195667115301324 (дата обращения 02.04.2018).

32. Jenkyns H.C. Geochemistry of oceanic anoxic events // Geochemistry, Geophysics, Geosystems. - 2010. - V. 11. - № 3. P. 1-30. URL: http://dx.doi.org/10.1029/2009GC002788 (дата обращения 14.03.2018).

33. The Albian oceanic anoxic events record in central and northern Tunisia: Geochemical data and paleotectonic controls / K. Zina, A. Hassene, R. Adel, J. Jérémy // Marine and Petroleum Geology. - 2018. - V. 93. - P. 145-165. URL: https://www.sciencedirect.com/science/article/pii/S0264817218301168 (дата обращения 02.04.2018).

34. Peters K.E., Cassa M.R. Applied source rock geochemistry // AAPG Special Volumes. Memoir 60: The petroleum system - from

Гарсия Бальса A.C., аспирант Инженерной школы природных ресурсов Национального исследовательского

Томского политехнического университета. source to trap / Eds. L.B. Magoon, W.G. Dow. - 1994. P. 93-120. URL: http://archives.datapages.com/data/specpubs/methodo2/data/a077/a077/0001/0050/0093.htm (дата обращения 05.04.2018).

35. Renz 0. The Cretaceous Ammonites of Venezuela. - Switzerland: Birkhüuser Verlag, 1982. - 132 p.

36. Méndez B.J. La Formación La Luna. Características de una cuenca anóxica en una plataforma de aguas someras // VII Congreso Geológico Venezolano. - 1989. - V. II. - P. 851-866.

37. Alberdi-Genolet M., Tocco R. Trace metals and organic geochemistry of the Machiques Member (Aptian-Albian) and La Luna Formation (Cenomanian-Campanian), Venezuela // Chemical Geology. - 1999. - V. 160. - P. 19-38. URL: https://www.sciencedirect.com/science/article/pii/S0009254199000443 (дата обращения 05.04.2018).

38. Hunt J.M. Petroleum Geochemistry and Geology. $2^{\text {nd }}$ ed. - New York, W.H. Freeman, 1995. - 743 p. URL: http://www.printrageous.com/petroleum-geochemistry-and-geology-john.pdf (дата обращения 05.04.2018).

39. Peters K., Walters C., Moldowan J. The biomarker guide. Biomarkers and isotopes in the environmental and human history. $2^{\text {nd }}$ ed. - Cambridge: Cambridge University Press, 2005. - V. I. $471 \mathrm{p}$.

Поступила 15.10.2018 2.

\section{Информация об авторах}


UDC 551.763.1

\title{
GEOLOGY OF THE APTIAN-ALBIAN COGOLLO GROUP CARBONATE PLATFORM AND IMPLICATIONS WITH THE OCEANIC ANOXIC EVENTS, MARACAIBO BASIN, NORTHWESTERN SOUTH AMERICA
}

\author{
Aura S. García, \\ garciaas@hw.tpu.ru \\ National Research Tomsk Polytechnic University, \\ 30, Lenin Avenue, Tomsk, 634050, Russia.
}

\begin{abstract}
The relevance of the research is caused by the need of driving boost a detailed and updated re-exploration process that allows not only predicting with accuracy the behavior of currently producing fields, but also expanding new possibilities for localization and development of oilfields resource in the Maracaibo basin of western Venezuela. The Cogollo group, represented by the Apón, Lisure and Maraca formations, constitutes a very important interval since it contains the main carbonate deposits and source rocks of the Cretaceous in the west of Venezuela. The levels of source rock correspond to the oceanic anoxic events $1 \mathrm{a}$ and $1 \mathrm{~b}$. The first event corresponds to Machiques Member, and the second one is located near the top of the Piché Member, both belonging to the Apón formation. As these events generated source rocks with high hydrocarbon potential, this remains the major subject of interest and research.

The main aim of the research is to recognize facies of the deposit and the correlation with adjacent wells, for location of reservoir units and their possible association with potential intervals of source rock of the Lower Cretaceous in the territory of Maracaibo basin, Venezuela.

The research objects are outcrop sections of the quarry in Cementos Catatumbo C.A of Perija Range, where the Lower Cogollo group carbonate succession and oil wells $X-1, X-15, X-21, X-14$ and $X-23$ are presented. Correlation analyses that include outcrops information at Perija Range are insufficiently justified and need to be clarified.

Research methods: sedimentological analysis of the carbonate rocks of the Cogollo Group, through the analysis of a section of surface in the quarry of Cementos Catatumbo C.A of Zulia state, Venezuela, integrating sedimentary, biostratigraphic, total organic carbon and Gamma-Ray data.

Results. The author has identified 14 microfacies associated with a scenario of a carbonate ramp basin. In the succession of rocks of the Apón Formation a maximum flooding surface and a drowning unconformity are distinguished. An approximated and estimated correlation taking into account stratigraphy, lithofacies and the GR responses was carried out with the outcrop section of quarry in Cementos Catatumbo C.A and oil wells X-1, X-15, X-21, X-14 and X-23.
\end{abstract}

Key words:

Carbonate platform, Cogollo group, Apón formation, Maracaibo basin, OAE 1a, OAE 1b.

The results introduced in the paper are the part of research project in collaboration with the researches of the project $P G O$ Golfo de Venezuela. The author appreciates the support of the members of the company PDVSA Exploration and Reservoir Integrated Studies - Puerto La Cruz, PDVSA Exploration-Maracaibo and PDVSA Geological Laboratory El Chaure - Puerto La Cruz when working at the research.

\section{REFERENCES}

1. Schlanger S.O., Jenkyns H.C. Cretaceous oceanic anoxic events: causes and consequences. Geologie en Mijnbouw, 1976, vol. 55, pp. 179-184. Available at: https://www.researchgate.net/publication/27710997_Cretaceous_Oceanic_Anoxic_Events_Causes and consequences (accessed 09 October 2018).

2. Takuto Ando, Ken Sawada, Kazuki Okano, Reishi Takashima, Hiroshi Nishi. Marine primary producer community during the mid-Cretaceous oceanic anoxic events (OAEs) $1 \mathrm{a}, 1 \mathrm{~b}$ and $1 \mathrm{~d}$ in the Vocontian Basin (SE France) evaluated from triaromatic steroids in sediments. Organic Geochemistry, 2017, vol. 106, pp. 13-24. Available at: https://www.sciencedirect.com/science/article/pii/S0146638017300335 (accessed 2 April 2018).

3. Arthur M.A., Jenkyns H.C., Brumsack H.J., Schlanger S.O. Stratigraphy, geochemistry, and paleoceanography of organic-carbon rich Cretaceous sequences. Cretaceous Resources, Events and Rhythms. Eds. R.N. Ginsburg, B. Beaudoin. Dordrecht, Kluwer Academic, 1990. Vol. 304, pp. 75-119. Available at: https:// www.researchgate.net/publication/230889733 Stratigraphy Geochemistry_and_Paleoceanography_of_Organic_CarbonRich Cretaceous Sequences (accessed 3 March 2018).

4. Gaona-Narvaez T., Maurrasse F.J.M.R., Etayo-Serna F. Geochemistry, palaeoenvironments and timing of Aptian organic-rich beds of the Paja Formation (Curití, Eastern Cordillera, Colom- bia). Geological Society. London, Special Publications, 2013. Vol. 382, pp. 31-48. Available at: https://core.ac.uk/downlo$\mathrm{ad} / \mathrm{pdf} / 46952723 . p d f$ (accessed 2 April 2018).

5. Méndez J., Baquero M. Sedimentación del Grupo Cogollo. Facies, Reservorios, Porosidad y Niveles de Roca Madre. Sistema Petrolero [Sedimentation of the Cogollo Group. Facies, reservoirs, porosity and source rock levels. Oil System]. Maracaibo, PDVSA Exploración, 2008. 222 p. In Spanish.

6. Hao Qingqing, Li Lintao, Zuo Yinhui, Chen Weijun, Wu Lei, Yi Junjie. Petroleum Distribution Characteristics of the Americas and the Exploration Prospect Analysis. Acta Geologica Sinica (English Edition), 2018, vol. 92, pp. 378-393. Available at: https://onlinelibrary.wiley.com/doi/pdf/10.1111/ 1755-6724.13512 (accessed 4 April 2018).

7. Boschetti T., Angulo B., Cabrera F., Vasquez J., Montero R. Hydrogeochemical characterization of oilfield waters from southeast Maracaibo Basin (Venezuela): Diagenetic effects on chemical and isotopic composition. Marine and Petroleum Geology, 2016, vol. 73, pp. 228-248. Available at: https://www.sciencedirect.com/science/article/pii/S0264817216300435 (accessed 3 April 2018).

8. Liborius-Parada A., Slatt R.M. Geological Characterization of La Luna Formation as an Unconventional Resource in Lago De Maracaibo Basin, Venezuela. Geological Characterization of La Luna 
Formation as an Unconventional Resource in Lago De Maracaibo Basin, Venezuela. SPE/AAPG/SEG Unconventional Resources Technology Conference. San Antonio, Texas, USA, 2016. pp. 1-20. Available at: https://www.onepetro.org/conferencepaper/URTEC-2461968-MS (accessed 5 April 2018).

9. Méndez J.A., Méndez J., Reyes D., Whilchy R. The Cogollo Group and the oceanic anoxic events 1a and 1b, Maracaibo basin, Venezuela. Brazilian Journal of Geology, 2015, vol. 45, pp. 41-61. Available at: https://www.researchgate.net/publication/282743319_The_Cogollo_Group_and_the_oceanic_anoxic_events_1a_and_1b_Maracaibo_basin_Venezuela (accessed 5 April 2018).

10. Pinto J., Ortega S., Medina C., León L., Oropeza H., Rodríguez I. Geología Sedimentaria de la Sucesión Barremiense-Cenomaniense, Grupo Cogollo-Basal La Luna, en la Región Central de la Cuen ca de Maracaibo [Sedimentary Geology of the Barremian-Cenomanian succession, Cogollo Group-Basal La Luna, in the Central Region of the Maracaibo Basin]. Caracas, PDVSA-Intevep, 2009. 194 p. In Spanish.

11. Zabanbark A., Lobkovsky L.I. Structural features and oil-and-gas bearing of the Caribbean. Oceanology, 2017, vol. 57, no. 5, pp. 799-814. In Rus. Available at: https://elibrary.ru/item.asp? id $=30258158$ (accessed 3 April 2018).

12. González C., Iturralde J., Picard X. Geología de Venezuela y sus Cuencas Petrolíferas. Caracas, Foninves, 1980. Vol. 1, 1001 p. Available at: https://es.scribd.com/doc/22828562/Geologia-deVenezuela-y-sus-Cuencas-Petroliferas-Parte-1-Gonzalez-de-Juana (21 February 2018).

13. Mann P., Escalona A., Castillo M. Regional geologic and tectonic setting of the Maracaibo supergiant basin, western Venezuela. AAPG Bulletin, 2006, vol. 90, no. 4, pp. 445-477. Available at: https://pubs.geoscienceworld.org/aapgbull/article-abstract/90/4/445/132738/regional-geologic-and-tectonic-setting-of-the?redirectedFrom=fulltext (accessed 5 April 2018).

14. Parnaud F., Gou Y., Pascual J.C., Capello M.A., Truskowski I., Passalacqua H. Stratigraphic synthesis of western Venezuela. Petroleum Basins of South America. AAPG Memoir: Petroleum Basins of South America, 1995, vol. 62, pp. 681-698. Available at: https://pubs.geoscienceworld.org/books/book/1367/chapter/107170184/stratigraphic-synthesis-of-western-venezuela (accessed 26 May 2018).

15. Castillo V., Benkovics L., Cobos C., Demuro D., Franco A. Perla Field: The Largest Discovery Ever in Latin America. AAPG Special Volumes. Memoir 113: Giant Fields of the decade 2000-2010, 2017, pp. 141-152. Available at: http://archives.datapages.com/ data/specpubs/memoir113/data/141_aapg-sp2020141.htm (accessed 3 April 2018).

16. Bartok P., Reijers T., Juhasz I. Lower Cretaceous Cogollo Group, Maracaibo Basin, Venezuela: sedimentology, diagenesis, and petrophysics. AAPG Bulletin, 1981, vol. 65, pp. 1110-1134. Available at: http://archives.datapages.com/data/bulletns/1980-81/ data/pg/0065/0006/1100/1110.htm (accessed 14 March 2018).

17. Eva A.N., Burke K., Mann P., Y Wadge G. Four-phase tectonostratigraphic development of the southern Caribbean. Marine and Petroleum Geology, 1989, vol. 6, pp. 9-21. Available at: https://www.sciencedirect.com/science/article/pii/ 026481728990072X (accessed 5 April 2018).

18. Ostos M., Yoris F., Llallemant H. Overview of the southeast Caribbean-South American plate boundary zone. Special Paper of the Geological Society of America. Caribbean-South American plate interactions, Venezuela. Eds. H.G. Avé Lallemant, V.B. Sisson, 2005, vol. 394, pp. 53-89. Available at: https://www.researchgate.net/publication/283942470_0verview_of the_southeast_Caribbean-South_American_plate_boundary_zone (accessed 5 April 2018).

19. Rod E., Maync W. Revision of Lower Cretaceous stratigraphy of Venezuela. AAPG Bulletin, 1954, vol. 38, no. 2 pp. 193-283. Available at: https://pubs.geoscienceworld.org/aapgbull/artic- le-abstract/38/2/193/33988/revision-of-lower-cretaceous-stratigraphy-of (accessed 5 April 2018).

20. Renz 0. Estratigrafía del Cretáceo en Venezuela Occidental [Cretaceous stratigraphy in Western Venezuela]. Boletin del Ministerio de Minas e Hidrocarburos, 1958, vol. 5, no. 10, pp. 3-48. In Spanish.

21. Erlich R.N., Macsotay 0., Nederbragt A.J., Lorente M.A. Birth and death of the Late Cretaceous "La Luna Sea», and origin of the Tres Esquinas phosphorites. Journal of South American Earth Sciences, 2000, vol. 13, pp. 21-45. Available at: https://www. sciencedirect.com/science/article/pii/S089598110000016X (accessed 1 June 2018).

22. Martínez R.J.I., Hernandez R. Evolution and drowning of the Late Cretaceous Venezuelan carbonate platform. Journal of South American Earth Sciences, 1992, vol. 5, pp. 197-210. Available at: https://www.sciencedirect.com/science/article/pii/ 089598119290038Z (accessed 1 June 2018).

23. Escalona A., Mann P. Sequence-stratigraphic analysis of Eocene clastic foreland basin deposits in central Lake Maracaibo using high-resolution well correlation and 3-D seismic data. AAPG Bulletin, 2006, vol. 90, pp. 581-623. Available at: https://pubs.geoscienceworld.org/aapgbull/article-abstract/90/4/581/ 132752 /sequence-stratigraphic-analysis-of-eocene-clastic?redirectedFrom=fulltext (accessed 5 April 2018).

24. Flügel E. Microfacies of Carbonate Rocks. Analysis, Interpretation and Application. Springer, 2004. 921 p. Available at: https://www.springer.com/us/book/9783662087268 (accessed 4 June 2018).

25. Burchette T.P., Wright P. Carbonate ramp depositional systems. Sedimentary Geology, 1992, vol. 79, pp. 3-57. Available at: https://www.sciencedirect.com/science/article/pii/ 003707389290003A (accessed 2 July 2018).

26. Choquette P.W., Pray L.C. Geologic nomenclature and classification of porosity in sedimentary carbonates. AAPG Bulletin, 1970, vol. 54, no. 2, pp. 207-250. Available at:http://archives.datapages.com/data/bulletns/1968-70/data/pg/0054/0002/0200/ 0207.htm?doi=10.1306 \% 2F5D25C98B-16C1-11D78645000102C1865D (accessed 2 July 2018).

27. Tucker M.E., Wright D. Carbonate sedimentology. USA, Blackwell Science, 2004, 482 p. Available at: https://onlinelibrary.wiley.com/doi/10.1002/9781444314175.fmatter (accessed 2 July 2018).

28. Bartok P., Y Reijers T. Patrones depositacionales, diagénesis y evaluación de reservorios en el Grupo Cogollo, Cretáceo Inferior, Cuenca de Maracaibo [Depositional patterns, diagenesis and reservoir evaluation in the Cogollo Group, Lower Cretaceous, Maracaibo Basin]. Maracaibo, Maraven S.A. and Shell, 1979. 28 p. In Spanish.

29. Bartok P., Reijers T., Juhasz I. Lower Cretaceous Cogollo Group, Maracaibo Basin, Venezuela: sedimentology, diagenesis, and petrophysics. AAPG Bulletin, 1981, vol. 65, pp. 1110-1134. Available at: http://archives.datapages.com/data/bulletns/1980-81/ data/pg/0065/0006/1100/1110.htm (accessed 14 March 2012).

30. Audemard F. Tectonics of western Venezuela. Ph.D. Thesis. Houston, Texas, USA, 1992. 245 p. Available at: https://scholarship.rice.edu/handle/1911/16556? show=full (accessed 14 March 2018)

31. Sun Y.W., Li X., Zhao G., Liu H., Zhang Y. Aptian and Albian atmospheric $\mathrm{CO}_{2}$ changes during oceanic anoxic events: Evidence from fossil Ginkgo cuticles in Jilin Province, Northeast China. Cretaceous Research, 2016, vol. 62, pp. 130-141. Available at: https://www.sciencedirect.com/science/article/pii/ S0195667115301324 (accessed 2 April 2018).

32. Jenkyns H.C. Geochemistry of oceanic anoxic events. Geochemistry, Geophysics, Geosystems, 2010, vol. 11, no. 3. pp. 1-30. Available at: http://dx.doi.org/10.1029/2009GC002788 (accessed 14 March 2018). 
33. Zina K., Hassene A., Adel R., Jérémy J. The Albian oceanic anoxic events record in central and northern Tunisia: Geochemical data and paleotectonic controls. Marine and Petroleum Geology, 2018, vol. 93, pp. 145-165. Available at: https://www.sciencedirect.com/science/article/pii/S0264817218301168 (accessed 2 April 2018)

34. Peters K.E., Cassa M.R. Applied source rock geochemistry. $A A P G$ Special Volumes. Memoir 60: The petroleum system - From source to trap, 1994, pp. 93-120. Available at:http://archives.datapages.com/data/specpubs/methodo2/data/a077/a077/0001/ 0050/0093.htm (accessed 5 April 2018).

35. Renz 0. The Cretaceous Ammonites of Venezuela. Switzerland, Birkhüuser Verlag, 1982. 132 p.

36. Méndez B.J. La Formación La Luna. Características de una cuenca anóxica en una plataforma de aguas someras [La Luna Formation. Characteristics of an anoxic basin in a shallow water platform]. VII Congreso Geológico Venezolano, 1989, vol. II, pp. 851-866. In Spanish.
37. Alberdi-Genolet M., Tocco R. Trace metals and organic geochemistry of the Machiques Member (Aptian-Albian) and La Luna Formation (Cenomanian-Campanian), Venezuela. Chemical Geology, 1999, vol. 160, pp. 19-38. Available at: https://www.sciencedirect.com/science/article/pii/S0009254199000443 (accessed 5 April 2018).

38. Hunt J.M. Petroleum Geochemistry and Geology. $2^{\text {nd }}$ ed. New York, W.H. Freeman, 1995. 743 p. Available at: http://www. printrageous.com/petroleum-geochemistry-and-geologyjohn.pdf (accessed 5 April 2018).

39. Peters K., Walters C., Moldowan J. The biomarker guide. Biomarkers and isotopes in the environmental and human history. $2^{\text {nd }}$ ed. Cambridge, Cambridge University Press, 2005. Vol. I, 471 p.

Received: 15 October 2018.

Information about the authors

Aura S. García, postgraduate student, National Research Tomsk Polytechnic University. 